\title{
Synthesis, molecular docking studies, and antimicrobial evaluation of pyrano[2, 3- c]pyrazole derivatives
}

\author{
Samy A. El-Assalya, Abd El-Hamid A. Ismail ${ }^{\mathrm{b}}$, Hamed Abdel Bary ${ }^{\mathrm{b}}$ and Mohamed G. \\ Abouelenein $^{b^{*}}$
}

${ }^{a}$ Natural and Microbial Products Chemistry Department, National Research Centre (NRC), Dokki, Giza, Egypt ${ }^{b}$ Chemistry Department, Faculty of Science, Menofia University, Shebin El-Koam, Menofia, Egypt

\begin{tabular}{l} 
C H R O N I C L E \\
\hline Article history: \\
Received November 18, 2020 \\
Received in revised form \\
March 10, 2021 \\
Accepted March 10, 2021 \\
Available online \\
March 10, 2021 \\
\hline Keywords: \\
Pyrano[2, 3-c]pyrazole \\
Spirooxindoles \\
Pyrimidine \\
Antimicrobial \\
Molecular docking
\end{tabular}

\section{Introduction}

The main challenge facing scientists today is a pollution-free environment. ${ }^{1}$ Thus, synthetic organic chemists centered their attention on developing practical methods, conditions, usage of materials, and the reaction media depending on green chemistry principles. ${ }^{2}$ Multicomponent reactions (MCRs) are processes for constructing molecular diversity and complexity through a concerted reaction involving a combination of three or more reactants. ${ }^{3}$ The MCRs evolvement has brought about a paradigm shift in current day research in synthetic organic, medicinal, and combinatorial chemistry by complying with the green chemistry principles in terms of frugality of energy and steps and waste pot MCRs allow swift approach to combinatorial libraries of bioactive scaffolds and -lessening. ${ }^{4}$ One complex heterocycles, especially in drug discovery. ${ }^{5}$ MCRs offer significant features over conventionally linear-type synthesis by dint of their building up various organic molecules from easily pot process with inherent flexibility, selective convergence, good-obtainable reactants in a one

* Corresponding author. Tel: +2-01068628458

E-mail address: moh.gamal89@yahoo.com (M. G. Abouelenein)

(C) 2021 Growing Science Ltd. All rights reserved. doi: $10.5267 /$ j.ccl.2021.3.003 
productivity, facile execution, and high yields. ${ }^{6}$ The first multicomponent reaction was described in 1850 by Strecker, and subsequently, various reactions of such type have been published. ${ }^{7,8}$

In recent years, the synthesis of $4-H$ pyran unit bearing heterocyclic compounds has gained a lot of interest, as they are essential precursors to promising biologically active compounds in the field of medicinal chemistry. ${ }^{9}$ Pyranopyrazoles are referred to as a fused five-member pyrazole ring with a sixmember pyran ring. Pyrano[2,3-c] pyrazoles are even more prominent at the study level because of their high pharmacological importance and due to the various activities of the heterocyclic core. The dihydropyrano[2,3-c] pyrazole scaffolds are comprehended to display a broad spectrum of biological activities as anti-cancer, ${ }^{10}$ anti-inflammatories, ${ }^{11}$ antimicrobial, ${ }^{12}$ antidepressant, ${ }^{13}$ anti-tuberculous, ${ }^{14}$ anti-tumour, ${ }^{15}$ anticonvulsant,${ }^{16}$ anti-platelet, ${ }^{17}$ molluscicidal agents, ${ }^{18}$ herbicides, ${ }^{19}$ insecticides, ${ }^{20}$ vasodilators, ${ }^{21}$ analgesics, ${ }^{22}$ and medicinal ingredients. ${ }^{23}$ Furthermore, 6-amino-4-(3,4dihydroxyphenyl)-3-methyl-1,4-dihydropyrano[2, 3-c]pyrazole-5-carbonitrile has been reported as a possible human Chk1 kinase inhibitor. ${ }^{24}$ Furthermore, some of these substances are widely used as cosmetics, ${ }^{25}$ pigments, ${ }^{26}$ lubricant oil antioxidants, ${ }^{27}$ effective steel corrosion inhibitors, ${ }^{28}$ pharmaceutical ingredients, and biodegradable agrochemical agents. ${ }^{29}$ They also play a significant role as crucial synthetic intermediates. ${ }^{30}$

With respect to biological significance, the dihydropyrano[2, 3-c]pyrazole derivatives synthesis has experienced a resurgence of interest by the organic chemists. This is reflected in a vast number of synthetic methods through multicomponent reactions of this class of compounds. In 1973, scientist Stolle first synthesized a pyranopyrazole derivative by the condensation of hydrazine hydrate and ethyl acetoacetate. $^{31}$ Junek and co-workers synthesized a pyrano pyrazole poly-nitrile derivative by conducting a reaction, in the presence of triethylamine, between 5-methyl-2-phenyl-2,4-dihydro-3 $\mathrm{H}$ pyrazol-3-one and ethene-1,1,2,2-tetracarbonitrile. ${ }^{32}$ In 1974, Otto produced 2-amino-4-substituted pyrano[2, 3-c]pyrazole-3-carbonitriles by addition of malononitrile to 4-arylidene-5-methyl-2,4dihydro-3H-pyrazol-3-one. ${ }^{33}$ Gradually, a number of synthetic methods including bases has been developed to produce various 6-amino-4-alkyl/aryl-3-methyl-1,4-dihydropyrano[2, 3-c]pyrazole-5carbonitriles by the reaction of arylidienemalononitrile with 3-methylpyrazoline-5-ones or by the condensation of 4-arylidienepyrazoline-5-one with malononitrile. ${ }^{34}$ Sharanin and co-workers have developed a three-component reaction between pyrazolone, an aldehyde and malononitrile in ethanol using triethylamine as the catalyst. ${ }^{35}$ Shestopalov and co-workers reported the synthesis of pyrazolopyran via a three-component condensation between $N$-methyl-4-piperidone, pyrazoline-5-one, and malononitrile in absolute ethanol. ${ }^{36}$ However, this reaction occurred only on heating or when induced by electrochemical methods under an inert atmosphere. Peng and co-workers have developed a two-component reaction involving pyran derivatives and hydrazine hydrate to obtain pyranopyrazoles in water. ${ }^{37}$ The reaction was promoted by a combination of microwave and ultrasonic irradiation. In the present work, we report an efficient and ecofriendly four-component reaction protocol in aqueous medium at room temperature for the synthesis of pyranopyrazole derivatives using conventional method. The synthesized compounds were screened for their antimicrobial activity, further molecular docking studies were carried out to recognize the drug-receptor interactions.

\section{Results and Discussion}

\subsection{Chemistry}

Base-catalyzed one-pot four-component approach was conducted to synthesize various 1,4dihydro-pyrano[2,3-c]pyrazole derivatives using a clean method of simple conditions to adopt the principles of green chemistry. The synthesis of 1,4-dihydro-pyrano [2,3-c]pyrazoles derivatives M1M21 in 85-93\% yields could be easily accomplished by tandem Knoevenagel condensation/Michael addition/imine-enamine tautomerism/O-cyclization through the reaction of hydrazine hydrate, $96 \% 1$, $\beta$-keto ester as ethyl acetoacetate or diethyl malonate $\mathbf{2}$, aryl/heteroaryl aldehyde $\mathbf{3}$, and enolizable active methylene compounds as malononitrile or ethyl cyanoacetate or diethyl malonate 4 in the 
presence of piperidine as a catalyst ( $5 \mathrm{~mol} \%$ ) with vigorous stirring in an aqueous medium for $20 \mathrm{~min}$ at room temperature under an open atmosphere (Scheme 1). The spectral results for all new products are in good agreement with their chemical structures ( $c f$. experimental part for details).
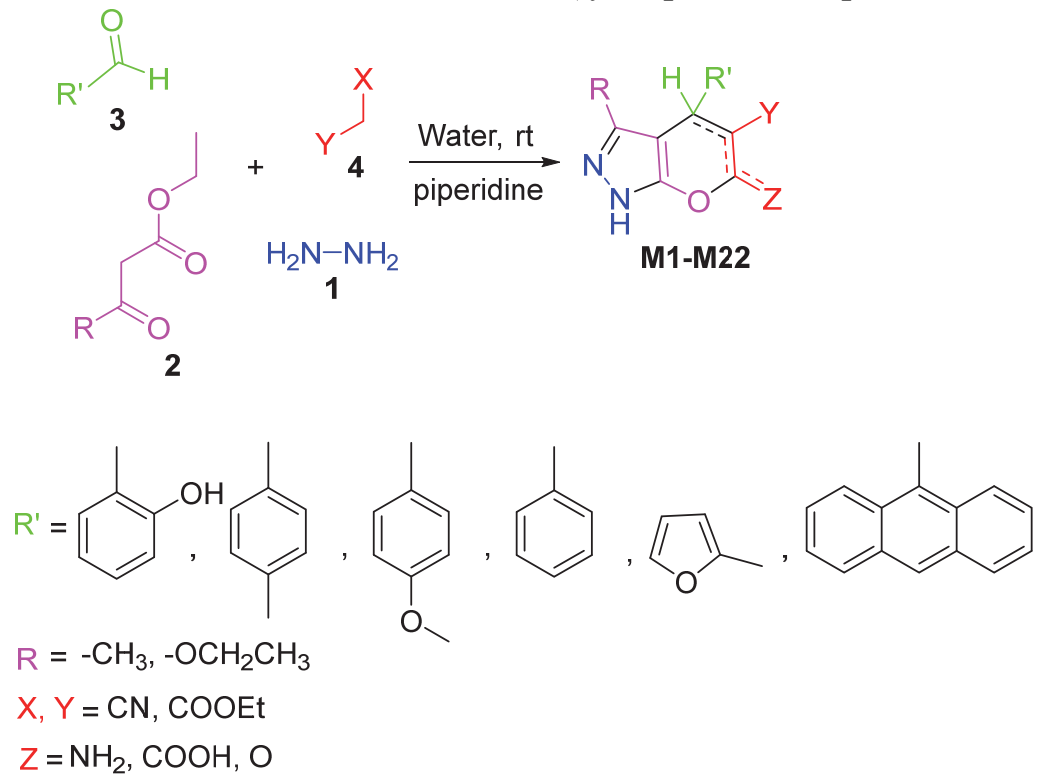

Scheme 1. One-pot synthesis of several pyrano[2, 3-c]pyrazoles M1-M22

The reaction sequence (Scheme 2) illustrates the construction of the desired compound M2a starting from the reaction of hydrazine hydrate, $96 \% \mathbf{1}$, ethyl acetoacetate $\mathbf{2}$, salicylaldehyde $\mathbf{3}$, and diethyl malonate 4 in the presence of a catalytic amount of piperidine $(5 \mathrm{~mol} \%)$. Unfortunately, we noticed that the isolated expected product M2a was not supported by spectral data, whereas spectral data agrees well with the unexpected compound M2. It worthy noted that the reason behind the formation of compound $\mathbf{M 2}$ instead of M2a lies in the reaction of salicylaldehyde with diethyl malonate, which does not follow the Knoevenagel condensation reaction as the other aryl/heteroaryl aldehydes, and thus does not form arylidene but rather ethyl 2-oxo- $2 H$-chromene-3-carboxylate. ${ }^{38}$

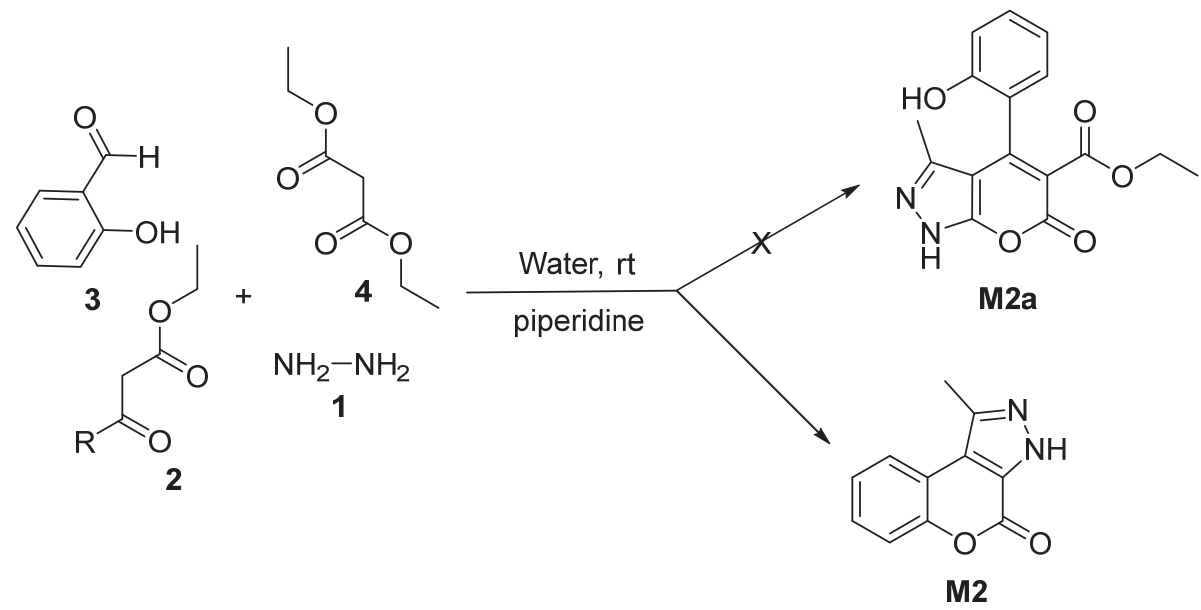

Scheme 2. One-pot synthesis of compound M2

IR spectrum shows an intense band at $1708 \mathrm{~cm}^{-1}$ due to the lactone carbonyl group. Whereas, pyrazole ring $\mathrm{NH}$ stretching band was observed at $3392 \mathrm{~cm}^{-1} .{ }^{1} \mathrm{H}$ NMR further confirmed the un expected compound $\mathbf{M} 2$, wherein the $\mathrm{NH}$ proton of the pyrazole ring appeared as a singlet peak at 12.5 
ppm; however, the most significant note is the absence of the ester group protons signals from the spectrum which confirms the unexpected compound M2. ${ }^{13} \mathrm{C}$ NMR spectra also contributed significantly to confirm the structure of this compound M2, as it revealed the presence of a characteristic signal for the lactone carbonyl group at $\delta 162.55 \mathrm{ppm}$ but also was freed from the ester group carbons signals. The elemental analysis values and the mass spectral data of the unexpected synthesized compound $\mathbf{M} 2$ are in good agreement with the theoretical data.

It should be noted that basic hydrolysis of the ester group of M6 was observed upon carrying out the reaction involving hydrazine hydrate, $96 \% \mathbf{1}$, ethyl acetoacetate 2, 4-Methylbenzaldehyde 3, and ethyl cyanoacetate 4 in the presence of an excess catalytic amount of piperidine $(10 \mathrm{~mol} \%)$ with vigorous stirring for $20 \mathrm{~min}$ in an aqueous medium at room temperature under an open atmosphere to yield the corresponding carboxylic acid derivative M22. The structure of compound $\mathbf{M 2 2}$ was verified by means of IR, ${ }^{1} \mathrm{H}$ NMR, ${ }^{13} \mathrm{C}$ NMR, mass spectra, and elemental analysis. The IR spectrum showed characteristic absorption bands corresponding to the carboxylic acid hydroxyl group and amino groups at $3464-3186,3413,3333,3278 \mathrm{~cm}^{-1}$, respectively, in addition to a very sharp absorption band at 1707 $\mathrm{cm}^{-1}$ corresponding to the carboxylic acid carbonyl group. The ${ }^{1} \mathrm{H}$ NMR spectra established the characteristic signal of the amino group protons at $\delta 7.65 \mathrm{ppm}$, further to a broad singlet signal at $\delta$ $12.88 \mathrm{ppm}$ for the carboxylic acid proton. ${ }^{13} \mathrm{C}$ NMR spectra also highlighted the existence of a characteristic signal for the carboxylic acid carbonyl group at $\delta 174.55 \mathrm{ppm}$. Furthermore, the elemental analysis values and mass spectral experimental data of the synthesized compound $\mathbf{M 2 2}$ have perfect conformity with the theoretical data.

Isatin is a privileged lead molecule for designing potential pharmacological agents as spirooxindole-based organic compounds. The spirooxindole system is the core structure of many pharmacological agents and natural alkaloids. ${ }^{39}$ Spirooxindoles, especially those spiro-annulated with heterocycles at the 3-position, have shown good biological activities. ${ }^{40}$ Due to the pharmacological activities of spirooxindole motifs and the bioactivity of pharmacophores such as naphthoquinone, indandione, pyrazolone, and pyrimidine derivatives, we sought to develop a single structural framework by combining spirooxindole, pyran, and pyrazole motifs for emergent interest in designing novel hybrid polycyclic heterocycles which may inherit biological properties of both spirooxindole and pharmacophore structures.

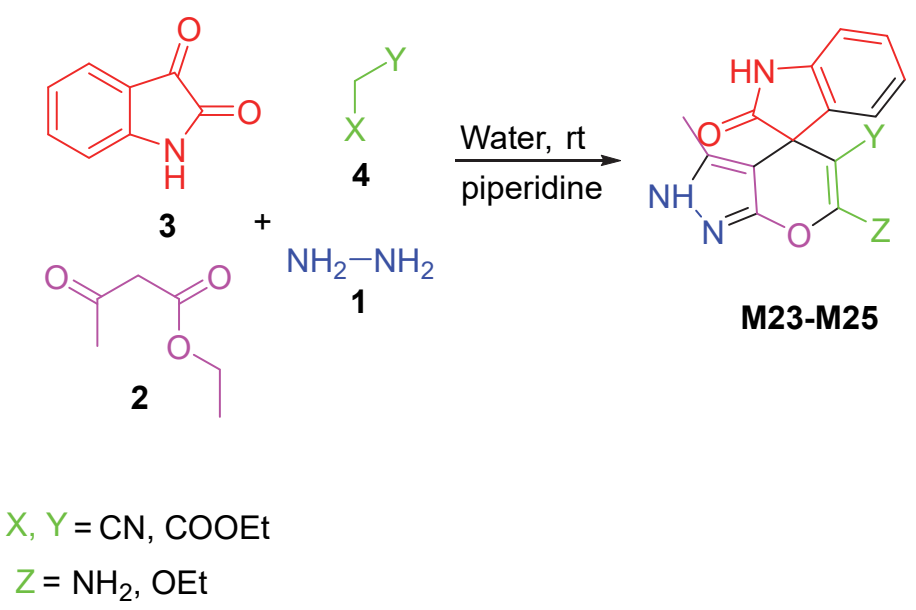

Scheme 3. One-pot synthesis of compounds M23-M25 
The synthesis of spiro[indoline-3,4'-pyrano[2,3-c]pyrazole] derivatives M23-M25 in 78-82\% yields could be easily achieved by tandem Knoevenagel condensation/Michael addition/imineenamine tautomerism/ $O$-cyclization through the reaction of hydrazine hydrate $96 \% 1, \beta$-keto ester as ethyl acetoacetate 2, isatin $\mathbf{3}$, and enolizable active methylene compounds as malononitrile or ethyl cyanoacetate or diethyl malonate $\mathbf{4}$ in the presence of piperidine as a catalyst with vigorous stirring for $25 \mathrm{~min}$ in aqueous medium at room temperature under an open atmosphere (Scheme 4). An aqueous mixture of hydrazine hydrate and ethyl acetoacetate was firstly stirred at room temperature for about 5 min then, isatin, active methylene compounds, and piperidine as the base catalyst were introduced.

The structures of the target compounds M23-M25 were confirmed by spectral $\left(\mathrm{IR},{ }^{1} \mathrm{H}\right.$ NMR, ${ }^{13} \mathrm{C}$ NMR, and Mass) and elemental analyses. According to ${ }^{1} \mathrm{H}$ and ${ }^{13} \mathrm{C}$ NMR spectra, the proton and carbon resonance signals of aliphatic and aromatic groups were observed at the expected regions. The mass spectra of the title compounds were verified by ESI spectra, where the $\mathrm{m} / \mathrm{z}$ values of molecular ion peaks were in complete agreement with the calculated molecular weight for each compound. The purity levels of compounds were determined by elemental analysis $(\mathrm{C}, \mathrm{H}, \mathrm{N})$, and the results were almost identical to the calculated values ( $c f$. experimental part for details).

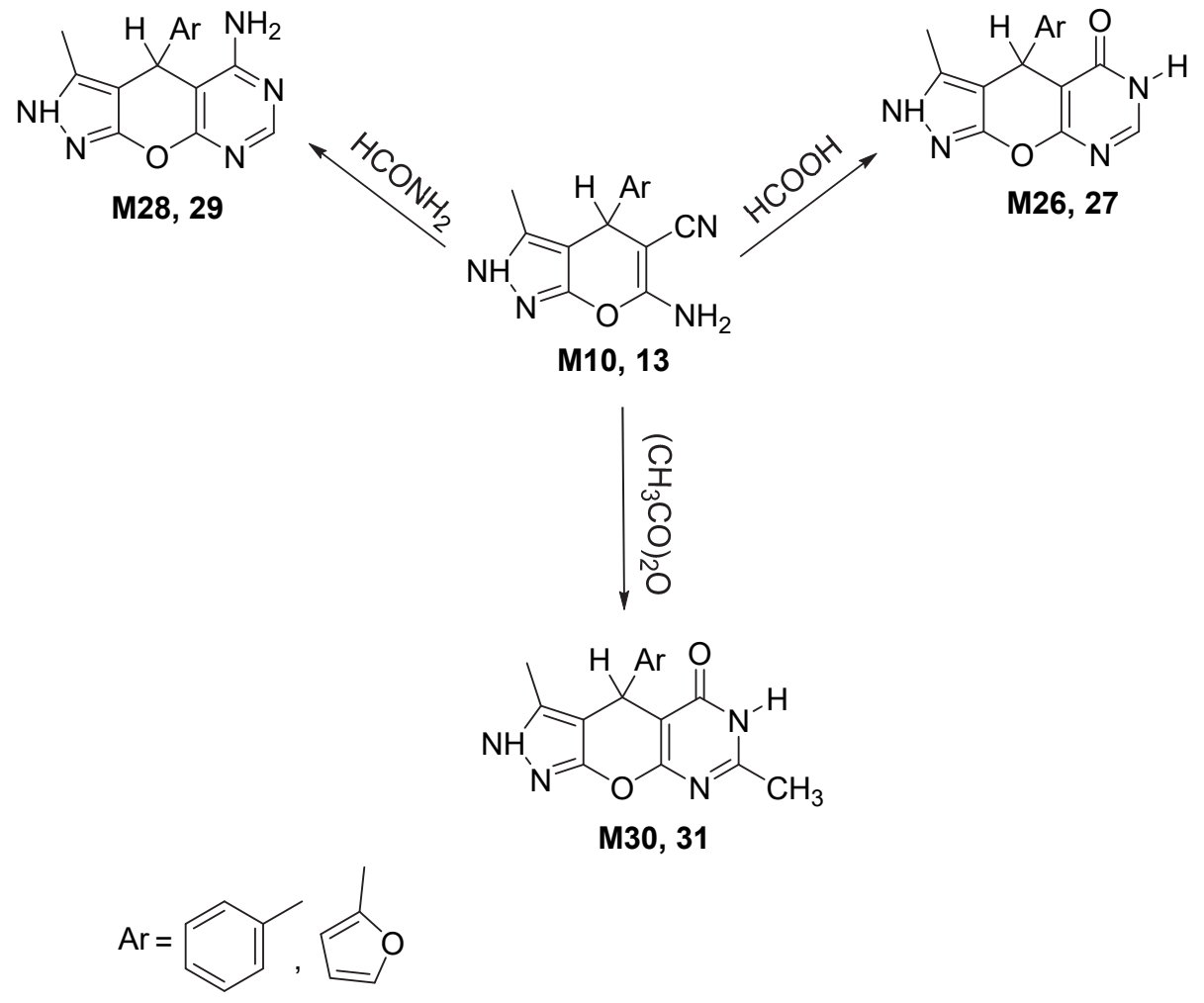

Scheme 4. synthesis of pyrano[2, 3-c]pyrazoles M26-M31

Conducting the four-component reaction in this sequence (Scheme 1 and Scheme 4) removed any risk of aldehyde/isatin reaction with hydrazine hydrate and assured that all amount of aldehyde/isatin would react with the active methylene compounds according to the Knoevenagel condensation reaction. This sequence led to diminishing the side reactions, reducing the amounts of impurities, and increasing the yield percentage. Literature survey revealed that the formal isoelectronic relation between pyrimidine and purine provided much attention to fused pyrimidines, especially pyranopyrimidine derivatives. ${ }^{41}$ They play an essential role as antipyretic, analgesic, antiinflammatory, antihypertensive drugs, herbicides, pesticides, and plant growth regulators. ${ }^{42}$ These considerable remarks inspired us for the synthesis of these new compounds with predictable bioefficacy. Various reactions of $o$-aminonitriles attached to aromatic or heterocyclic moieties with the familiar acylating agents and formic acid were stated. ${ }^{43}$ The resulting $o$-acylaminonitriles or the $o$ - 
formyl derivatives are of significant vitality since they can be straightforwardly converted to the corresponding pyrimidine derivatives by acid or base. Accordingly, it was noticed that cyclocondensation of pyrano[2, 3-c]pyrazoles M10, M13 with either formic acid or acetic anhydride afforded the corresponding pyrimidine- 4-one derivatives M26, M27, M30, and M31 (Scheme 4). The reaction is proposed to proceed via the hydrolysis of the cyano group to amide group and the formylation of the amino group or acetylation accompanied by a ring closure by eliminating water molecule to produce the pyrimidine- 4-one ring. The structures of the products got corroborated from their analytical along with spectral data. IR spectra were devoid of absorption band characteristic to cyano group and experienced the appearance of the absorption bands for the carbonyl group of the pyrimidine- 4-one ring at 1680-1667 $\mathrm{cm}^{-1}$. Besides refluxing the pyrano[2, 3-c]pyrazoles M10, M13 with formamide in dimethylformamide, the 4-amino pyrimidine derivatives M28, M29 were isolated via cyclocondensation reaction (Scheme 4). Thus, the cyano group absorption band was not perceived in the IR spectrum but revealed the appearance of the absorption bands for an amino group of the 4amino pyrimidine ring at $3410-2923 \mathrm{~cm}^{-1}$.

\subsection{Pharmacology}

\subsubsection{Antimicrobial Activity}

For both their anti-bacterial activity versus Gram-positive (B. subtilis, C. tetani, and S. pneumoniae), Gram-negative ( $S$. typhi, $P$. aeruginosa, and $V$. cholerae) bacterial strains, and antifungal efficiency versus three strains of fungi (C. krusei, A. fumigatus, and A. niger), the synthesized compounds M1-M31 were evaluated using the Broth microdilution method. ${ }^{44,}{ }^{45}$ The minimum inhibitory concentration (MIC) was the lowest concentration of the tested compound, which causes no noticeable growth (turbidity). With the like dilutions as those utilized in the experiments, the test medium complemented by DMSO was deemed as a control to guarantee that the solvent did not affect the bacterial or fungal growth. Consequently, DMSO was noted to not influence the microorganisms in the concentrations tested; the attained results are tabularized and discussed in Table 1.

The compounds M1-M31 anti-bacterial testing disclosed that nearly the vast majority of pyrano[2, 3-c]pyrazoles derivatives were extremely active versus Gram-positive bacterial strains. In case of $B$.

subtilis, the synthesised compounds $\mathbf{M 1}\left(\mathrm{CH}_{3}\right.$ substitution at $\mathrm{C}_{3}$ of pyrazole ring and 2-hydroxyphenyl, $\mathrm{CN}$, and $\mathrm{NH}_{2}$ substitutions on pyran ring), $\mathbf{M} 2\left(\mathrm{CH}_{3}\right.$ substitution at $\mathrm{C}_{3}$ of pyrazole ring fused with chromene ring), $\mathbf{M 3}\left(\mathrm{CH}_{3}\right.$ substitution at $\mathrm{C}_{3}$ of pyrazole ring and 2-hydroxyphenyl, COOEt, and $\mathrm{NH}_{2}$ substitutions on pyran ring), $\mathbf{M} 4\left(\mathrm{CH}_{3}\right.$ substitution at $\mathrm{C}_{3}$ of pyrazole ring and $p$-tolyl, $\mathrm{CN}$, and $\mathrm{NH}_{2}$ substitutions on pyran ring), $\mathbf{M 5}\left(\mathrm{CH}_{3}\right.$ substitution at $\mathrm{C}_{3}$ of pyrazole ring and $p$-tolyl, COOEt, and Oxo substitutions on pyran ring), $\mathbf{M 6}\left(\mathrm{CH}_{3}\right.$ substitution at $\mathrm{C}_{3}$ of pyrazole ring and $p$-tolyl, COOEt, and $\mathrm{NH}_{2}$ substitutions on pyran ring), $\mathbf{M} 7\left(\mathrm{CH}_{3}\right.$ substitution at $\mathrm{C}_{3}$ of pyrazole ring and 4-methoxyphenyl, $\mathrm{CN}$, and $\mathrm{NH}_{2}$ substitutions on pyran ring), $\mathbf{M 8}\left(\mathrm{CH}_{3}\right.$ substitution at $\mathrm{C}_{3}$ of pyrazole ring and 4methoxyphenyl, COOEt, and Oxo substitutions on pyran ring), $\mathbf{M 1 0}\left(\mathrm{CH}_{3}\right.$ substitution at $\mathrm{C}_{3}$ of pyrazole ring and phenyl, $\mathrm{CN}$, and $\mathrm{NH}_{2}$ substitutions on pyran ring), $\mathbf{M 1 1}\left(\mathrm{CH}_{3}\right.$ substitution at $\mathrm{C}_{3}$ of pyrazole ring and phenyl, COOEt, and oxo substitutions on pyran ring), $\mathbf{M 1 3}\left(\mathrm{CH}_{3}\right.$ substitution at $\mathrm{C}_{3}$ of pyrazole ring and furan-2-yl, $\mathrm{CN}$, and $\mathrm{NH}_{2}$ substitutions on pyran ring), $\mathbf{M 1 4}\left(\mathrm{CH}_{3}\right.$ substitution at $\mathrm{C}_{3}$ of pyrazole ring and furan-2-yl, COOEt, and oxo substitutions on pyran ring), $\mathbf{M 1 6}\left(\mathrm{OCH}_{2} \mathrm{CH}_{3}\right.$ substitution at $\mathrm{C}_{3}$ of pyrazole ring and 2-hydroxyphenyl, $\mathrm{CN}$, and $\mathrm{NH}_{2}$ substitutions on pyran ring), $\mathbf{M 1 7}\left(\mathrm{OCH}_{2} \mathrm{CH}_{3}\right.$ substitution at $\mathrm{C}_{3}$ of pyrazole ring and $p$-tolyl, $\mathrm{CN}$, and $\mathrm{NH}_{2}$ substitutions on pyran ring), $\mathrm{M18}$ $\left(\mathrm{OCH}_{2} \mathrm{CH}_{3}\right.$ substitution at $\mathrm{C}_{3}$ of pyrazole ring and 4-methoxyphenyl, $\mathrm{CN}$, and $\mathrm{NH}_{2}$ substitutions on pyran ring), $\mathrm{M19}\left(\mathrm{OCH}_{2} \mathrm{CH}_{3}\right.$ substitution at $\mathrm{C}_{3}$ of pyrazole ring and phenyl, $\mathrm{CN}$, and $\mathrm{NH}_{2}$ substitutions on pyran ring), $\mathbf{M 2 0}\left(\mathrm{OCH}_{2} \mathrm{CH}_{3}\right.$ substitution at $\mathrm{C}_{3}$ of pyrazole ring and anthracen-9-yl, $\mathrm{CN}$, and $\mathrm{NH}_{2}$ substitutions on pyran ring), $\mathbf{M 2 1}\left(\mathrm{OCH}_{2} \mathrm{CH}_{3}\right.$ substitution at $\mathrm{C}_{3}$ of pyrazole ring and furan-2-yl, $\mathrm{CN}$, and $\mathrm{NH}_{2}$ substitutions on pyran ring), and $\mathbf{M 2 2}\left(\mathrm{CH}_{3}\right.$ substitution at $\mathrm{C}_{3}$ of pyrazole ring and $p$-tolyl, $\mathrm{COOH}$, and $\mathrm{NH}_{2}$ substitutions on pyran ring), $\mathbf{M} 23\left(\mathrm{CH}_{3}\right.$ substitution at $\mathrm{C}_{3}$ of pyrazole ring and $\mathrm{NH}_{2}$ and $\mathrm{CN}$ substitutions on spiro[indoline-3,4'-pyran]-2-one ring), $\mathbf{M} 24\left(\mathrm{CH}_{3}\right.$ substitution at $\mathrm{C}_{3}$ of 
pyrazole ring and COOEt and $\mathrm{OCH}_{2} \mathrm{CH}_{3}$ substitutions on spiro[indoline-3,4'-pyran]-2-one ring), $\mathbf{M 2 5}$ $\left(\mathrm{CH}_{3}\right.$ substitution at $\mathrm{C}_{3}$ of pyrazole ring and $\mathrm{NH}_{2}$ and COOEt substitutions on spiro[indoline-3,4'pyran]-2-one ring), $\mathbf{M 2 6}\left(\mathrm{CH}_{3}\right.$ substitution at $\mathrm{C}_{3}$ of pyrazole ring and furan-2-yl and oxo substitutions on pyrano[2,3-d]pyrimidine ring), $\mathbf{M 2 7}\left(\mathrm{CH}_{3}\right.$ substitution at $\mathrm{C}_{3}$ of pyrazole ring and phenyl and oxo substitutions on pyrano[2,3- $d$ ] pyrimidine ring), $\mathbf{M 2 8}\left(\mathrm{CH}_{3}\right.$ substitution at $\mathrm{C}_{3}$ of pyrazole ring and furan2-yl and $\mathrm{NH}_{2}$ substitutions on pyrano[2,3- $d$ ] pyrimidine ring), $\mathbf{M 2 9}\left(\mathrm{CH}_{3}\right.$ substitution at $\mathrm{C}_{3}$ of pyrazole ring and phenyl and $\mathrm{NH}_{2}$ substitutions on pyrano[2,3- $d$ ] pyrimidine ring), $\mathbf{M 3 0}\left(\mathrm{CH}_{3}\right.$ substitution at $\mathrm{C}_{3}$ of pyrazole ring and furan-2-yl, $\mathrm{CH}_{3}$, and oxo substitutions on pyrano[2,3-d]pyrimidine ring), and M31 $\left(\mathrm{CH}_{3}\right.$ substitution at $\mathrm{C}_{3}$ of pyrazole ring and furan-2-yl, $\mathrm{CH}_{3}$, and oxo substitutions on pyrano[2,3d]pyrimidine ring) exposed, at a lower concentration, higher activity than ciprofloxacin as standard drug. Moreover, compounds $\mathrm{M12}\left(\mathrm{CH}_{3}\right.$ substitution at $\mathrm{C}_{3}$ of pyrazole ring and phenyl, COOEt, and $\mathrm{NH}_{2}$ substitutions on pyran ring) and $\mathbf{M 1 5}\left(\mathrm{CH}_{3}\right.$ substitution at $\mathrm{C}_{3}$ of pyrazole ring and furan-2-yl, COOEt, and $\mathrm{NH}_{2}$ substitutions on pyran ring) exhibited comparable activity with ciprofloxacin against B. subtilis, whereas, at a lower concentration, compound $\mathbf{M 9}\left(\mathrm{CH}_{3}\right.$ substitution at $\mathrm{C}_{3}$ of pyrazole ring and 4-methoxyphenyl, COOEt, and $\mathrm{NH}_{2}$ substitutions on pyran ring) exhibited lower activity than ciprofloxacin as standard drug. In case of C. tetani, the synthesised compounds M1-M5, M8-M31 exposed, at a lower concentration, higher activity than ciprofloxacin as standard drug. Moreover, compound M6 exhibited comparable activity with ciprofloxacin while, compound M7 exhibited lower activity than ciprofloxacin as standard drug. In case of $S$. pneumoniae, the synthesised compounds M2, M3, M5, M7, M9, M10, M11, M14, M16, M8, M20, M21, M22, M24, M25, M26, M27, and M28 exposed, at a lower concentration, higher activity than ciprofloxacin as standard drug. Moreover, compounds M4, M23, and M29 exhibited comparable activity with ciprofloxacin while, the rest of synthetic compounds exhibited lower activity than ciprofloxacin as standard drug. The activity of M1M31 compounds was estimated versus three Gram-negative bacterial strains; it was observed that, at a lower concentration, the synthetic compounds exposed selective activities versus ciprofloxacin as standard drug. In case of $S$. typhi, the synthesised compounds M1, M6, M8, M14, M15, M19, M21, M22, M23, M29, M30, and M31 exposed, at a lower concentration, higher activity than ciprofloxacin as standard drug. Moreover, compounds M3, M17, M27, and M28 exhibited comparable activity with ciprofloxacin while, the rest of synthetic compounds exhibited lower activity than ciprofloxacin as standard drug. In case of $P$. aeruginosa, the synthesised compounds M1, M2, M3, M6, M7, M10, M11, M14, M18, M21, M22, M23, and M31 exposed, at a lower concentration, higher activity than ciprofloxacin as standard drug. Moreover, only compounds M16, M19, and M20 exhibited comparable activity with ciprofloxacin while, the rest of synthetic compounds exhibited lower activity than ciprofloxacin as standard drug. In case of $V$. cholerae, the synthesised compounds M4, M6, M7, M13, M15, M17, M21, M24, and M25 exposed, at a lower concentration, higher activity than ciprofloxacin as standard drug. Moreover, compounds M1, M12, M14, and M22 exhibited comparable activity with ciprofloxacin while, the rest of synthetic compounds exhibited lower activity than ciprofloxacin as standard drug. In the antifungal screening of compounds M1-M31 against three strains of fungi $(C$. krusei, A. fumigatus, and A. niger), at a lower concentration, almost the whole compounds exhibited lower efficiency than nystatin griseofulvin as reference drugs except, compound M6, which was almost equally active compared to griseofulvin as a standard drug in case of $C$. krusei; the study outcomes are described in Table 1. However, the majority of the synthesized compounds were clearly noted to exhibit lower antifungal activity compared to their anti-bacterial activity, and this is due to the fact that antibiotics are one of the main risk factors for fungal infections as depicted in Table 1, where compounds, for instance, M14, M21, M22, and M23 which exhibited higher anti-bacterial efficacy, but, in contrast, they exhibited lower antifungal efficacy and dramatically allowed fungal growth. ${ }^{46}$ 
Table 1. In vitro antimicrobial efficiency results of the compounds M1-31

\begin{tabular}{|c|c|c|c|c|c|c|c|c|c|}
\hline \multirow{3}{*}{ Entry } & \multicolumn{9}{|c|}{ Minimum inhibitory concentration in $\mu \mathrm{g} / \mathrm{mL}$ (MIC) } \\
\hline & \multicolumn{3}{|c|}{ Gram +ve bacteria } & \multicolumn{3}{|c|}{ Gram -ve bacteria } & \multicolumn{3}{|c|}{ Fungai strains } \\
\hline & B. s. & C.t. & S. $p$. & S. t. & P. $a$. & V.c. & C. $k$. & A. $f$. & A. $n$. \\
\hline M1 & 3.57 & 3.57 & 5.00 & 1.87 & 1.25 & 3.125 & 5.00 & 6.25 & 7.50 \\
\hline M2 & 1.25 & 5.00 & 0.93 & 7.50 & 1.87 & 3.75 & 8.75 & 10.00 & 7.50 \\
\hline M3 & 1.87 & 0.93 & 1.25 & 3.125 & 1.87 & 5.00 & 8.75 & 7.50 & 6.25 \\
\hline M4 & 1.25 & 0.10 & 3.125 & 3.57 & 7.50 & 1.87 & 7.50 & 10.00 & 12.50 \\
\hline M5 & 1.87 & 1.00 & 2.50 & 5.00 & 3.57 & 6.25 & 8.75 & 12.50 & 6.25 \\
\hline M6 & 1.87 & 6.25 & 3.75 & 1.87 & 0.93 & 2.50 & 3.125 & 7.50 & 6.25 \\
\hline M7 & 3.125 & 7.50 & 2.50 & 6.25 & 1.25 & 1.00 & 3.75 & 5.00 & 7.50 \\
\hline M8 & 1.87 & 3.125 & 6.25 & 1.87 & 6.25 & 7.50 & 6.25 & 10.00 & 3.75 \\
\hline M9 & 7.50 & 3.125 & 1.25 & 6.25 & 3.75 & 5.00 & 10.00 & 8.75 & 12.50 \\
\hline M10 & 3.57 & 1.00 & 1.25 & 5.00 & 1.87 & 6.25 & 5.00 & 6.25 & 7.50 \\
\hline M11 & 3.125 & 1.00 & 2.50 & 3.75 & 1.25 & 5.00 & 7.50 & 5.00 & 8.75 \\
\hline M12 & 6.25 & 2.50 & 5.00 & 3.57 & 7.50 & 3.125 & 8.75 & 7.50 & 5.00 \\
\hline M13 & 2.50 & 1.87 & 5.00 & 6.25 & 3.57 & 1.25 & 10.00 & 3.75 & 7.50 \\
\hline M14 & 0.75 & 0.10 & 1.25 & 1.87 & 2.50 & 3.125 & 3.75 & 8.75 & 12.50 \\
\hline M15 & 6.25 & 1.25 & 7.50 & 2.50 & 3.75 & 1.00 & 10.00 & 7.50 & 6.25 \\
\hline M16 & 3.125 & 1.87 & 2.50 & 5.00 & 3.125 & 6.25 & 12.50 & 8.75 & 6.25 \\
\hline M17 & 1.00 & 1.25 & 3.75 & 3.125 & 5.00 & 0.93 & 8.75 & 10.00 & 7.50 \\
\hline M18 & 0.75 & 1.00 & 1.25 & 3.75 & 2.50 & 5.00 & 8.75 & 7.50 & 6.25 \\
\hline M19 & 1.00 & 2.50 & 3.75 & 2.50 & 3.125 & 6.25 & 12.50 & 10.00 & 8.75 \\
\hline M20 & 1.25 & 0.93 & 1.87 & 3.75 & 3.125 & 7.50 & 12.5 & 5.00 & 7.50 \\
\hline M21 & 0.10 & 1.00 & 0.10 & $\mathbf{0 . 5 0}$ & 0.75 & 2.50 & 8.75 & 7.50 & 10.00 \\
\hline M22 & 0.50 & 1.00 & 1.25 & 0.75 & 2.50 & 3.125 & 7.50 & 12.50 & 8.75 \\
\hline M23 & 1.87 & 2.50 & 3.125 & 2.50 & 1.25 & 3.75 & 10.00 & 7.50 & 8.75 \\
\hline M24 & 2.50 & 3.75 & 1.25 & 6.25 & 5.00 & 2.50 & 6.25 & 7.50 & 10.00 \\
\hline M25 & 1.87 & 3.125 & 2.50 & 5.00 & 6.25 & 1.25 & 7.50 & 12.50 & 8.75 \\
\hline M26 & 3.75 & 2.50 & 1.87 & 3.75 & 5.00 & 7.50 & 7.50 & 8.75 & 10.00 \\
\hline M27 & 1.87 & 1.25 & 1.00 & 3.125 & 6.25 & 3.75 & 10.00 & 7.50 & 12.50 \\
\hline M28 & 1.87 & 3.75 & 2.50 & 3.125 & 7.50 & 5.00 & 8.75 & 7.50 & 10.00 \\
\hline M29 & 2.50 & 5.00 & 3.125 & 2.50 & 3.75 & 6.25 & 10.00 & 8.75 & 12.50 \\
\hline M30 & 2.50 & 1.87 & 6.25 & 2.50 & 5.00 & 7.50 & 6.25 & 10.00 & 5.00 \\
\hline M31 & 1.25 & 3.125 & 7.50 & 1.00 & 2.50 & 6.25 & 7.50 & 8.75 & 12.50 \\
\hline Ciprofloxacin & 6.25 & 6.25 & 3.125 & 3.125 & 3.125 & 3.125 & - & - & - \\
\hline Griseofulvin & - & - & - & - & - & - & 3.125 & 1.25 & 1.25 \\
\hline Nystatin & - & - & - & - & - & - & 1.25 & 1.00 & 1.00 \\
\hline
\end{tabular}

\subsubsection{Molecular docking study}

In order to take a supplemental step for the determination of the mode of action of the studied compounds, the molecular-docking research was applied for the binding mode determination and the antimicrobial in silico study versus penicillin-binding protein $(\mathrm{PBPb})$ that act as drug target for antimicrobial agent. For the orientation and position of the detected ligand in the crystal structure to be represented, the authenticity of the docking parameters and methods should be emphasized, so the cocrystal ligand redocking was necessary. Confirming the approval with the accuracy and parameters of the docking protocols, the RMSD value difference was $<2 \AA$ among cocrystal ligand to the authentic cocrystal ligand.

Based on antimicrobial assays, compound M21 was the most promising anti-bacterial agent against both Gram-negative and Gram-positive bacterial strains; therefore, we have investigated its activity against the penicillin-binding protein. Molecular docking results showed that compound M21 has a tremendous binding affinity with $\mathrm{PBPb}$ with a free binding of energy less than the PNM, the cocrystalized ligand of $\mathrm{PBPb}(-7.3 \mathrm{Kcal} / \mathrm{mole},-7.2 \mathrm{Kcal} / \mathrm{mole}$, respectively). Besides, compound M21 was capable of forming 5 hydrophobic interactions and 4 critical hydrogen bonds with the key amino acid residues in the $\mathrm{PBPb}$ binding pocket (Table 2 and Fig. 1). 
Table 2. The docking study results of the most auspicious testified compound (M21) into $\mathrm{PBPb}$ binding pocket (PDB: 3UDI) in comparing with the co-crystallized ligand.

\begin{tabular}{|c|c|c|c|c|c|}
\hline \multirow[t]{3}{*}{ Entry } & \multirow[t]{3}{*}{$\Delta G_{b}{ }^{a}$} & \multicolumn{4}{|c|}{ Types of interactions } \\
\hline & & \multicolumn{3}{|c|}{ Hydrogen bonding } & Hydrophobic \\
\hline & & No & $\underset{b}{\text { Length } \AA}$ & $\mathbf{A A}^{c}$ & $\mathbf{A A}^{c}$ \\
\hline \multirow[t]{4}{*}{ M21 } & -7.3 & 4 & 3.214 & Ser434 & Ile710, Leu484, Leu486, Leu526, Val649 \\
\hline & & & 2.279 & Ser487 & \\
\hline & & & 2.400 & Thr670 & \\
\hline & & & 2.438 & Thr670 & \\
\hline \multirow[t]{7}{*}{ RL } & -7.2 & 7 & 3.019 & Asn489 & Leu486, Ala676 \\
\hline & & & 2.755 & Thr672 & \\
\hline & & & 2.774 & Thr672 & \\
\hline & & & 3.377 & Ser487 & \\
\hline & & & 3.554 & Lys669 & \\
\hline & & & 2.991 & Thr670 & \\
\hline & & & 2.634 & Thr670 & \\
\hline
\end{tabular}

\section{Reference drug}
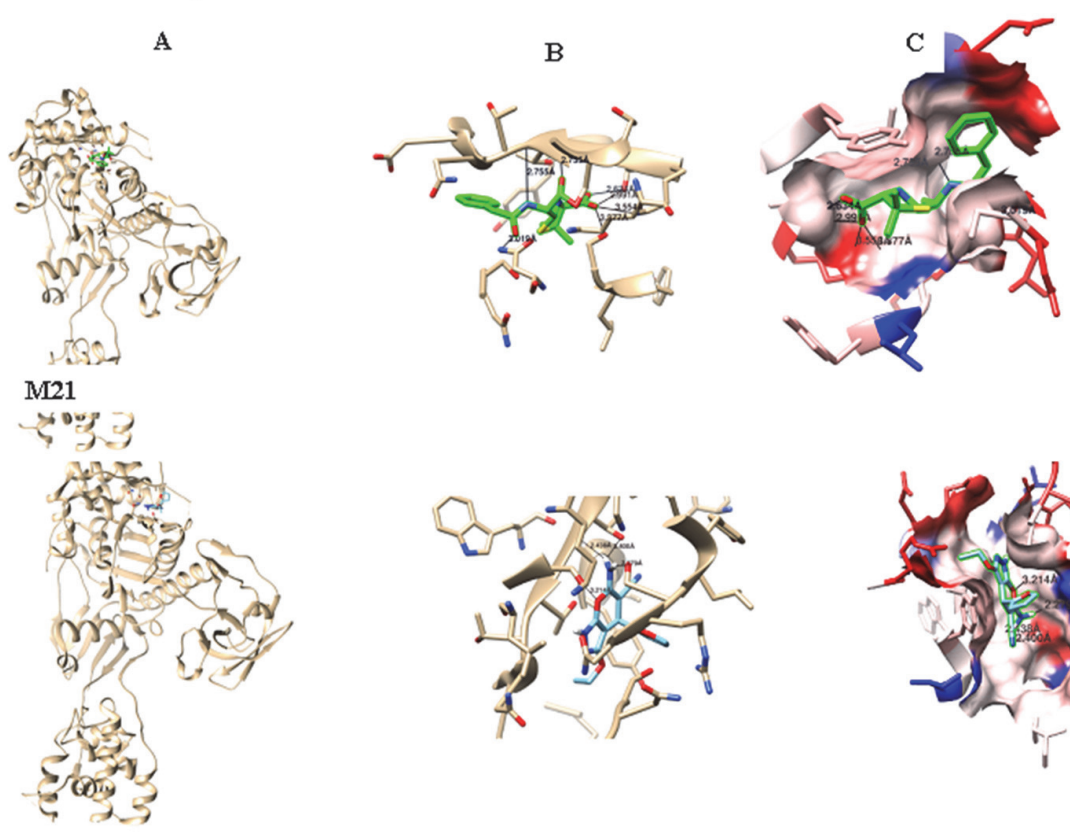

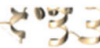
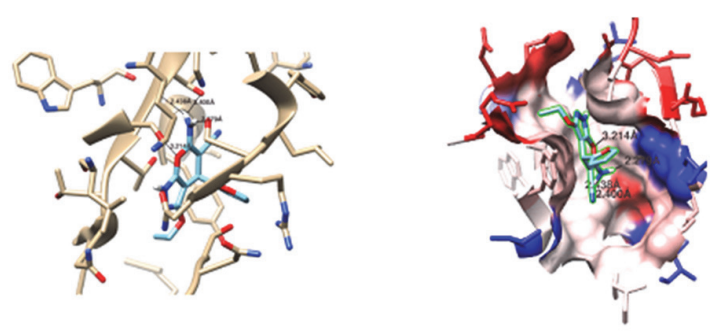

Fig. 1. Compound M21 interaction with $\mathrm{PBPb}$ protein, A) 3D interaction, B) hydrogen bond formation, and $\mathrm{C}$ ) hydrophobic interaction representation

\section{Conclusions}

In this study, we have conducted a successful green approach for a sequence of pyrano[2, 3c]pyrazole as well as pyrazolopyranopyrimidine derivatives to be synthesized within a short period with yields $78-93 \%$. The target compounds were elucidated by means of an array of spectral techniques, encompassing IR, ${ }^{1} \mathrm{H}$ NMR, ${ }^{13} \mathrm{C}$ NMR, and mass spectrometry, and the purity levels of the compounds were determined through elemental analysis $(\mathrm{C}, \mathrm{H}, \mathrm{N})$. Toward antimicrobial activity, the vast majority 
of the synthesized compounds manifested excellent efficiency. Moreover, compound M21 was the highly efficient synthesized scaffold in anti-bacterial and molecular docking simulation studies. Furthermore, the presented results highlighted a newly prospective way of discovering drugs with antimicrobial activity.

\section{Experimental}

\subsection{Materials and Methods}

All the chemicals were purchased by commercial sources and used without further purification. The purity of the synthesized compounds and the progress of the reactions were monitored by thin-layer chromatography (TLC), which was performed with Merck pre-coated silica gel 60 F254 aluminum sheets and visualized using UV light at $254 \mathrm{~nm}$. The melting points were measured on the Stuart science melting point apparatus by the open capillary method and are uncorrected. ${ }^{1} \mathrm{H}$ NMR and ${ }^{13} \mathrm{C}$ NMR spectra were measured on a JEOL ECA-500 II spectrometer $(500 \mathrm{MHz}$ or $100 \mathrm{MHz}$, respectively) using dimethylsulfoxide (DMSO-d6) as solvent and tetramethylsilane (TMS) as an internal standard. Chemical shifts are reported in $\delta$ part per million ( $\mathrm{ppm}$ ) relative to internal tetramethylsilane standard (TMS, $\delta 0.00$ ). The peak patterns are indicated as follows: s, singlet; $d$, doublet; t, triplet; m, multiplet; q, quartet; br, broad. The coupling constant, $J$, is reported in Hertz $(\mathrm{Hz})$. The IR spectra were recorded on a Thermo Fisher Nicolet IS10, USA spectrometer (Mansoura University), Egypt, by the KBr disc method, and mass spectra were recorded using GC/MS SHIMADZU spectrophotometer operating at $70 \mathrm{eV}$ at the Micro analytical center (Al-Azhar University). The CHN elemental analyses of all the compounds were recorded by an automatic analyzer (CHNS Vario EL III-Elementar Analyzer, Germany) at the Micro Analytical Unit (Al-Azhar University).

\subsection{General procedure}

\subsubsection{General procedure for preparation of pyrano[2, 3-c]pyrazole derivatives (M1-M15), (M16-M21)}

To a well-stirred an aqueous mixture of hydrazine hydrate, $96 \% 1(1 \mathrm{mmol})$ and ethyl acetoacetate or diethyl malonate $2(1 \mathrm{mmol})$ for $5 \mathrm{~min}$ in a $50 \mathrm{~mL}$ rounded bottom flask, aryl/heteroaryl aldehyde 3 ( $1 \mathrm{mmol})$, either malononitrile or ethyl cyanoacetate or diethyl malonate 4 ( $1 \mathrm{mmol})$, and piperidine $(5$ mol \%) were successively added at room temperature under an open atmosphere with vigorous stirring for $20 \mathrm{~min}$. The reaction progress, in each case, was monitored by TLC (eluent: ethyl acetate/ $n$-hexane, 1:2). After completion of the reaction, the precipitated solid, in each case, was collected by filtration, washed with cold water and then with a mixture of (ethyl acetate/ $n$-hexane) (20:80) and dried well. The obtained products were purified, in each case, by recrystallization from ethanol.

\subsubsection{General procedure for preparation of pyrano[2, 3-c]pyrazole derivative (M22)}

To a well-stirred an aqueous mixture of hydrazine hydrate, $96 \% 1(1 \mathrm{mmol})$ and ethyl acetoacetate $2(1 \mathrm{mmol})$ for $5 \mathrm{~min}$ in a $50 \mathrm{~mL}$ rounded bottom flask, 4-Methylbenzaldehyde 3 (1 mmol), ethyl cyanoacetate $4(1 \mathrm{mmol})$ and piperidine $(10 \mathrm{~mol} \%)$ were successively added at room temperature under an open atmosphere with vigorous stirring for $20 \mathrm{~min}$. The reaction progress was monitored by TLC (eluent: ethyl acetate/ $n$-hexane, 1:2). After completion of the reaction, the precipitated solid was collected by filtration, washed with cold water and then with a mixture of (ethyl acetate/ $n$-hexane) (20:80), and dried well. The obtained product was purified by recrystallization from ethanol.

\subsubsection{General procedure for preparation of spiro[indoline-3,4'-pyrano[2, 3-c]pyrazole derivatives (M23-M25)}

To a well-stirred an aqueous mixture of hydrazine hydrate, $96 \% 1(1 \mathrm{mmol})$ and ethyl acetoacetate $2(1 \mathrm{mmol})$ for $5 \mathrm{~min}$ in a $50 \mathrm{~mL}$ rounded bottom flask, isatin $3(1 \mathrm{mmol})$, either malononitrile or ethyl cyanoacetate or diethyl malonate $4(1 \mathrm{mmol})$, and piperidine $(5 \mathrm{~mol} \%)$ were successively added at room 
temperature under an open atmosphere with vigorous stirring for $25 \mathrm{~min}$. The reaction progress, in each case, was monitored by TLC (eluent: ethyl acetate/ $n$-hexane, 1:2). After completion of the reaction, the precipitated solid, in each case, was collected by filtration, washed with cold water, and then with a mixture of (ethyl acetate/ $n$-hexane) (20:80), and dried well. The product obtained, in each case, was purified by recrystallization from ethanol.

4.2.4 General procedure for preparation of pyrazolo[4',3':5,6]pyrano[2,3-d]pyrimidine derivatives (M26, M27)

A mixture of either compound M10 or M13 (5 mmol) and formic acid (20 mL) was refluxed for 4 h. The solvent was evaporated under vacuum, and the formed precipitate, in each case, was collected by filtration, washed several times with cold water, dried well, and purified by recrystallization from ethanol.

4.2.5 General procedure for preparation of pyrazolo[4',3':5,6]pyrano[2,3-d]pyrimidine derivatives (M28, M29)

A mixture of either compound M10 or M13 (5 mmol) with formamide (10 mL), formic acid (5 $\mathrm{mL}$ ), and dimethylformamide $(5 \mathrm{~mL})$ was refluxed for $6 \mathrm{~h}$. Then, in each case, the reaction mixture was allowed to cool at room temperature, and the formed precipitate, in each case, was collected by filtration, washed several times with cold water, dried well, and purified by recrystallization from ethanol.

\subsubsection{General procedure for preparation of pyrazolo[4',3':5,6]pyrano[2,3-d]pyrimidine derivatives (M30, M31)}

A mixture of either compound M10 or M13 $(5 \mathrm{mmol})$ in acetic anhydride $(10 \mathrm{~mL})$ and acetic acid $(10 \mathrm{~mL})$ was refluxed for $5 \mathrm{~h}$. Then, in each case, the reaction mixture was allowed to cool at room temperature and poured into ice-water $(20 \mathrm{~mL})$. The formed precipitate, in each case, was collected by filtration, washed several times with cold water, dried well, and purified by recrystallization from ethanol.

\subsection{Physical and Spectral Data}

6-amino-4-(2-hydroxyphenyl)-3-methyl-1,4-dihydropyrano[2, 3-c]pyrazole-5-carbonitrile (M1)

White powder; Yield 92\%; m.p: 225-227 ${ }^{\circ} \mathrm{C}$; IR (KBr) cm $\mathrm{cm}^{-1} 3447,3417,3351,2925,2187,1659,1609$; ${ }^{1} \mathrm{H}$ NMR (500 MHz, DMSO-d6) $\delta$ (ppm): 11.14 (s, 1H), 9.52 (s, br, 1H), 7.15-7.18 (m, 1H), 6.99-7.41 (m, 2H), 6.93-6.94 (d, $J=8.5 \mathrm{~Hz}, 1 \mathrm{H}), 6.68(\mathrm{~s}, 2 \mathrm{H}), 4.61(\mathrm{~s}, 1 \mathrm{H}), 1.95(\mathrm{~s}, 3 \mathrm{H}) ;{ }^{13} \mathrm{C} \mathrm{NMR}(100 \mathrm{MHz}$, DMSO- $\left.d_{6}\right) \delta$ (ppm): 160.18, 159.06, 148.36, 136.78, 131.27, 130.18, 124.05, 123.11, 120.36, 115.11, 105.11, 55.11, 35.47, 9.85; EIMS, $m / z[\mathrm{M}]^{+}$calcd: 268.10; found: 268.09; Elemental Analysis for $\mathrm{C}_{14} \mathrm{H}_{12} \mathrm{~N}_{4} \mathrm{O}_{2}(\%)$, Calcd: C, 62.68; H, 4.51; N, 20.88; found: C, 62.63; H, 4.47; N, 20.83.

\section{1-methylchromeno[3,4-c]pyrazol-4(3H)-one (M2)}

White powder; Yield 88\%; m.p: $189-191{ }^{\circ} \mathrm{C}$; IR (KBr) cm ${ }^{-1} 3392,3052,2922,1708,1619,1603 ;{ }^{1} \mathrm{H}$ NMR (500 MHz, DMSO- $\left.d_{6}\right) \delta(\mathrm{ppm}): 12.5(\mathrm{~s}, 1 \mathrm{H}), 7.77-7.80(\mathrm{~m}, 1 \mathrm{H})$, 7.61-7.64 (m, 2H), 7.54-7.56 $(\mathrm{d}, J=8.5 \mathrm{~Hz}, 1 \mathrm{H}), 2.13$ (s, 3H); ${ }^{13} \mathrm{C}$ NMR (100 MHz, DMSO- $\left.d_{6}\right) \delta$ (ppm): 162.55, 151.11, 139.27, 137.82, 130.91, 129.82, 126.2, 118.19, 112.5, 108.55, 13.09; EIMS, $m / z[\mathrm{M}]^{+}$calcd: 200.06 ; found: 200.05; Elemental Analysis for $\mathrm{C}_{11} \mathrm{H}_{8} \mathrm{~N}_{2} \mathrm{O}_{2}$ (\%), Calcd: C, 66.00; H, 4.03; N, 13.99; found: C, 65.94; H, 3.98; N, 13.92 . 
Ethyl 6-amino-4-(2-hydroxyphenyl)-3-methyl-1,4-dihydropyrano[2, 3-c]pyrazole-5-carboxylate (M3)

White powder; Yield 89\%; m.p: 224-226 ${ }^{\circ} \mathrm{C}$; IR (KBr) $\mathrm{cm}^{-1} 3438,3313,3214,2987,2921,1726,1657$, 1618; ${ }^{1} \mathrm{H}$ NMR (500 MHz, DMSO- $\left.d_{6}\right) \delta(\mathrm{ppm}): 12.10$ (s, 1H), 10.12 (s, br, 1H), 7.47 (s, 2H), 7.06-7.09 (m, 1H), 6.92-6.94 (m, 2H), 6.85-6.86 (d, J=8.5 Hz, 1H), $5.11(\mathrm{~s}, 1 \mathrm{H}), 4.05-4.11(\mathrm{q}, 2 \mathrm{H}), 1.82(\mathrm{~s}, 3 \mathrm{H})$, $1.23-1.26(\mathrm{t}, 3 \mathrm{H}) ;{ }^{13} \mathrm{C}$ NMR (100 MHz, DMSO- $\left.d 6\right) \delta(\mathrm{ppm}): 164.91,159.64,158.36,148.22,134.90$, $130.72,130.08,122.91,120.54,114.73,104.06,62.55,59.78,33.27,13.44,10.54 ;$ EIMS, $m / z[M]^{+}$ calcd: 315.12; found: 315.13; Elemental Analysis for $\mathrm{C}_{16} \mathrm{H}_{17} \mathrm{~N}_{3} \mathrm{O}_{4}(\%)$, Calcd: C, 60.94; H, 5.43; N, 13.33; found: C, 60.89; H, 5.39; N, 13.29.

\section{6-amino-3-methyl-4-(p-tolyl)-1,4-dihydropyrano[2, 3-c]pyrazole-5-carbonitrile (M4)}

White powder; Yield 91\%; m.p: 205-207 ${ }^{\circ} \mathrm{C}$; IR (KBr) cm $\mathrm{cm}^{-1} 3410,3378,3275,2923,2869,2192,1647$, 1601; ${ }^{1} \mathrm{H}$ NMR (500 MHz, DMSO- $d 6$ ) $\delta$ (ppm): 12.06 (s, 1H), 7.1-7.11 (d, $\left.J=8.5 \mathrm{~Hz}, 2 \mathrm{H}\right), 7.02-7.04$ $(\mathrm{d}, J=8.5 \mathrm{~Hz}, 2 \mathrm{H}), 6.82(\mathrm{~s}, 2 \mathrm{H}), 4.53(\mathrm{~s}, 1 \mathrm{H}), 2.26(\mathrm{~s}, 3 \mathrm{H}), 1.77(\mathrm{~s}, 3 \mathrm{H}) ;{ }^{13} \mathrm{C}$ NMR $(100 \mathrm{MHz}$, DMSO$\left.d_{6}\right) \delta$ (ppm): 160.73, 154.72, 142.54, 135.64, 135.09, 128.90, 127.64, 120.73, 97.82, 57.27, 35.82, 20.55, 9.63; EIMS, $m / z$ [M] $]^{+}$calcd: 266.12; found: 266.12; Elemental Analysis for $\mathrm{C}_{15} \mathrm{H}_{14} \mathrm{~N}_{4} \mathrm{O}(\%)$, Calcd: C, 67.65; H, 5.30; N, 21.04; found: C, 67.60; H, 5.26; N, 20.98.

\section{Ethyl 3-methyl-6-oxo-4-(p-tolyl)-1,6-dihydropyrano[2, 3-c]pyrazole-5-carboxylate (M5)}

White powder; Yield 85\%; m.p: $189-191{ }^{\circ} \mathrm{C}$; IR $(\mathrm{KBr}) \mathrm{cm}^{-1} 3190,3072,2925,1739,1706,1610 ;{ }^{1} \mathrm{H}$ NMR (500 MHz, DMSO- $\left.d_{6}\right) \delta$ (ppm): 12.25 (s, 1H), 7.24-7.26 (d, $\left.J=8.5 \mathrm{~Hz}, 2 \mathrm{H}\right), 7.17-7.19$ (d, $J=8.5$ $\mathrm{Hz}, 2 \mathrm{H}), 4.26-4.30$ (q, 2H), 2.24 (s, 3H), 1.88 (s, 3H), 1.24-1.28 (t, 3H); ${ }^{13} \mathrm{C}$ NMR (100 MHz, DMSO$\left.d_{6}\right) \delta$ (ppm): 164.17, 160.19, 153.81, 153.09, 152.36, 144.54, 136.36, 135.81, 128.72, 127.63, 103.46, 62, 20.73, 13.63, 10.55; EIMS, $m / z[\mathrm{M}]^{+}$calcd: 312.11; found: 312.10; Elemental Analysis for $\mathrm{C}_{17} \mathrm{H}_{16} \mathrm{~N}_{2} \mathrm{O}_{4}$ (\%), Calcd: C, 65.38; H, 5.16; N, 8.97; found: C, 65.33; H, 5.12; N, 8.92.

\section{Ethyl 6-amino-3-methyl-4-(p-tolyl)-1,4-dihydropyrano[2, 3-c]pyrazole-5-carboxylate (M6)}

White powder; Yield 86\%; m.p: 204-206 ${ }^{\circ} \mathrm{C}$; IR (KBr) cm ${ }^{-1} 3402,3268,3138,3013,2926,2859,1725$, 1670, 1603; ${ }^{1} \mathrm{H}$ NMR $\left(500 \mathrm{MHz}, \mathrm{DMSO}-d_{6}\right) \delta(\mathrm{ppm}): 12.15(\mathrm{~s}, 1 \mathrm{H}), 7.38(\mathrm{~s}, 2 \mathrm{H}), 6.98-7$ (d, $J=8.5 \mathrm{~Hz}$, 2H), 6.91-6.92 (d, $J=8.5 \mathrm{~Hz}, 2 \mathrm{H}), 5.04$ (s, 1H), 4.02-4.07 (q, 2H), 2.23 (s, 3H), $1.81(\mathrm{~s}, 3 \mathrm{H}), 1.16-1.20$ $(\mathrm{t}, 3 \mathrm{H}) ;{ }^{13} \mathrm{C}$ NMR $\left(100 \mathrm{MHz}, \mathrm{DMSO}-d_{6}\right) \delta(\mathrm{ppm}): 164.87,159.45,154.18,141.81,135.64,135.09$, 128.55, 127.27, 103.27, 61.82, 60.54, 33.64, 20.55, 13.45, 10.37; EIMS, $m / z[\mathrm{M}]^{+}$calcd: 313.14 ; found: 313.13; Elemental Analysis for $\mathrm{C}_{17} \mathrm{H}_{19} \mathrm{~N}_{3} \mathrm{O}_{3}(\%)$, Calcd: C, 65.16; H, 6.11; N, 13.41; found: C, 65.11; $\mathrm{H}, 6.05 ; \mathrm{N}, 13.37$.

6-amino-4-(4-methoxyphenyl)-3-methyl-1,4-dihydropyrano[2, 3-c]pyrazole-5-carbonitrile (M7)

White powder; Yield 91\%; m.p: 210-212 ${ }^{\circ} \mathrm{C}$; IR (KBr) $\mathrm{cm}^{-1} 3482,3259,3113,2960,2925,2191,1643$, 1604; ${ }^{1} \mathrm{H}$ NMR (500 MHz, DMSO- $d_{6}$ ) $\delta$ (ppm): 12.07 (s, 1H), 7.04-7.08 (m, 2H), 6.84-6.87 (m, 2H), $6.81(\mathrm{~s}, 2 \mathrm{H}), 4.52(\mathrm{~s}, 1 \mathrm{H}), 3.72(\mathrm{~s}, 3 \mathrm{H}), 1.78(\mathrm{~s}, 3 \mathrm{H}) ;{ }^{13} \mathrm{C}$ NMR (100 MHz, DMSO-d6) $\delta(\mathrm{ppm}): 160.36$, 159.73, 155.09, 139.82, 137.09, 136.55, 128.54, 121.27, 114.50, 98.91, 58.21, 55.45, 35.64, 9.93; EIMS, $m / z$ [M] $]^{+}$calcd: 282.11 ; found: 282.11 ; Elemental Analysis for $\mathrm{C}_{15} \mathrm{H}_{14} \mathrm{~N}_{4} \mathrm{O}_{2}$ (\%), Calcd: C, 63.82; H, 5.00; N, 19.85; found: C, 63.77; H, 4.94; N, 19.81 . 

(M8)

Ethyl 4-(4-methoxyphenyl)-3-methyl-6-oxo-1,6-dihydropyrano[2, 3-c]pyrazole-5-carboxylate

White powder; Yield 86\%; m.p: 195-197 ${ }^{\circ} \mathrm{C}$; IR (KBr) cm ${ }^{-1}$ 3400, 3086, 2967, 2930, 2841, 1729, 1705, 1601; ${ }^{1} \mathrm{H}$ NMR (500 MHz, DMSO- $\left.d_{6}\right) \delta(\mathrm{ppm}): 12.18(\mathrm{~s}, 1 \mathrm{H}), 7.39-7.45(\mathrm{~m}, 2 \mathrm{H}), 7.21-7.22(\mathrm{~m}, 2 \mathrm{H})$, 4.34-4.39 (q, 2H), $3.81(\mathrm{~s}, 3 \mathrm{H}), 1.94(\mathrm{~s}, 3 \mathrm{H}), 1.18-1.21(\mathrm{t}, 3 \mathrm{H}) ;{ }^{13} \mathrm{C}$ NMR (100 MHz, DMSO-d6) $\delta$ (ppm): 164.18, 160.90, 158.18, 157.45, 156.72, 152.72, 142.54, 136.91, 136.36, 128.36, 114.72, 98.73, 61.82, 55.63, 14, 10.91; EIMS, $m / z[\mathrm{M}]^{+}$calcd: 328.11; found: 328.12; Elemental Analysis for $\mathrm{C}_{17} \mathrm{H}_{16} \mathrm{~N}_{2} \mathrm{O}_{5}(\%)$, Calcd: C, 62.19; H, 4.91; N, 8.53; found: C, 62.13; H, 4.87; N, 8.48.

Ethyl 6-amino-4-(4-methoxyphenyl)-3-methyl-1,4-dihydropyrano[2, 3-c]pyrazole-5-carboxylate (M9)

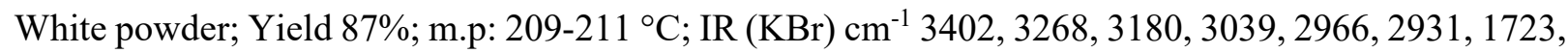
1666, 1601; ${ }^{1} \mathrm{H}$ NMR (500 MHz, DMSO- $\left.d 6\right) \delta(\mathrm{ppm}): 12.14(\mathrm{~s}, 1 \mathrm{H}), 7.71(\mathrm{~s}, 2 \mathrm{H}), 7.03-7.07$ (m, 2H), 6.86-6.87 (m, 2H), 5.12 (s, 1H), 4.28-4.33 (q, 2H), 3.73 (s, 3H), 1.89 (s, 3H), 1.14-1.17 (t, 3H); ${ }^{13} \mathrm{C}$ NMR (100 MHz, DMSO- $\left.d_{6}\right) \delta$ (ppm): 164.64, 159.27, 158.44, 155.62, 140.32, 136.62, 136.16, 128.19, 114.29, 98.36, 61.62, 60.36, 55.44, 33.63, 13.83, 10.72; EIMS, $m / z[\mathrm{M}]^{+}$calcd: 329.14 ; found: 329.13 ; Elemental Analysis for $\mathrm{C}_{17} \mathrm{H}_{19} \mathrm{~N}_{3} \mathrm{O}_{4}(\%)$, Calcd: C, 62.00; H, 5.81; N, 12.76; found: C, 61.95; H, 5.77; $\mathrm{N}, 12.71$.

6-amino-3-methyl-4-phenyl-1,4-dihydropyrano[2, 3-c]pyrazole-5-carbonitrile (M10)

White powder; Yield 93\%; m.p: 243-245 ${ }^{\circ} \mathrm{C}$; IR (KBr) cm $\mathrm{cm}^{-1} 3373,3311,3170,3021,2925,2191,1649$, 1599; ${ }^{1} \mathrm{H}$ NMR (500 MHz, DMSO- $\left.d_{6}\right) \delta(\mathrm{ppm}): 12.08(\mathrm{~s}, 1 \mathrm{H}), 7.29-7.32$ (t, $\left.J=7.5 \mathrm{~Hz}, 2 \mathrm{H}\right), 7.2-7.23$ (m, 1H), 7.15-7.16 (t, $J=7 \mathrm{~Hz}, 2 \mathrm{H}), 6.86(\mathrm{~s}, 2 \mathrm{H}), 4.58(\mathrm{~s}, 1 \mathrm{H}), 1.77(\mathrm{~s}, 3 \mathrm{H}) ;{ }^{13} \mathrm{C} \mathrm{NMR}(100 \mathrm{MHz}$, DMSO- $\left.d_{6}\right) \delta$ (ppm): 160.88, 154.77, 144.47, 135.57, 128.45, 127.48, 126.75, 120.82, 97.65, 57.15, 36.23, 9.75; EIMS, $m / z$ [M] $]^{+}$calcd: 252.10; found: 252.10; Elemental Analysis for $\mathrm{C}_{14} \mathrm{H}_{12} \mathrm{~N}_{4} \mathrm{O}(\%)$, Calcd: C, 66.65; H, 4.79; N, 22.21; found: C, 66.61; H, 4.74; N, 22.17.

Ethyl 3-methyl-6-oxo-4-phenyl-1,6-dihydropyrano[2, 3-c]pyrazole-5-carboxylate (M11)

White powder; Yield 88\%; m.p: 224-226 ${ }^{\circ} \mathrm{C}$; IR (KBr) $\mathrm{cm}^{-1} 3384,3034,2984,2938,1730,1707,1604$; ${ }^{1} \mathrm{H}$ NMR (500 MHz, DMSO-d6) $\delta(\mathrm{ppm}): 12.21(\mathrm{~s}, 1 \mathrm{H}), 7.30-7.34(\mathrm{t}, 2 \mathrm{H}), 7.21-7.24(\mathrm{~m}, 1 \mathrm{H}), 7.16-7.18$ $(\mathrm{t}, 2 \mathrm{H}), 4.22-4.27$ (q, 2H), 2.19 (s, 3H), 1.17-1.21 (t, 3H); ${ }^{13} \mathrm{C}$ NMR (100 MHz, DMSO-d6) $\delta(\mathrm{ppm})$ : 164.74, 161.27, 156.55, 155.82, 155.09, 143.83, 135.28, 128.55, 127.45, 126.73, 97.82, 61.63, 13.81, 10.73; EIMS, $m / z$ [M] $]^{+}$calcd: 298.10; found: 298.09; Elemental Analysis for $\mathrm{C}_{16} \mathrm{H}_{14} \mathrm{~N}_{2} \mathrm{O}_{4}(\%)$, Calcd: C, 64.42; H, 4.73; N, 9.39; found: C, 64.35; H, 4.66; N, 9.37.

Ethyl 6-amino-3-methyl-4-phenyl-1,4-dihydropyrano[2, 3-c]pyrazole-5-carboxylate (M12)

White powder; Yield 89\%; m.p: 242-244 ${ }^{\circ} \mathrm{C}$; IR (KBr) cm ${ }^{-1} 3338,3220,3126,3004,2960,2926$, 2855,1744, 1658, 1600; ${ }^{1} \mathrm{H}$ NMR (500 MHz, DMSO-d6) $\delta$ (ppm): 12.14 (s, 1H), 7.71 (s, 2H), 7.277.30 (t, 2H, Ar-H), 7.18-7.21 (m, 1H, Ar-H), 7.13-7.14 (t, 2H, Ar-H), 5.04 (s, 1H), 4.17-4.22 (q, 2H), $1.89(\mathrm{~s}, 3 \mathrm{H}), 1.24-1.28(\mathrm{t}, 3 \mathrm{H}) ;{ }^{13} \mathrm{C}$ NMR (100 MHz, DMSO-d6) $\delta(\mathrm{ppm}): 164.82,159.46,154.36$, $143.63,135.05,128.07,127.09,126.36,97.63,61.27,60.19,34.31,13.63,10.54 ; \mathrm{EIMS}, \mathrm{m} / z \mathrm{HM}^{+}$ calcd: 299.13; found: 299.12; Elemental Analysis for $\mathrm{C}_{16} \mathrm{H}_{17} \mathrm{~N}_{3} \mathrm{O}_{3}(\%)$, Calcd: C, 64.20; H, 5.72; N, 14.04; found: C, 64.15; H, 5.68; N, 13.99 .

6-amino-4-(furan-2-yl)-3-methyl-1,4-dihydropyrano[2, 3-c]pyrazole-5-carbonitrile (M13)

White powder; Yield 90\%; m.p: 230-232 ${ }^{\circ} \mathrm{C}$; IR (KBr) cm $\mathrm{cm}^{-1} 3357,3315,3172,2926,2187,1649,1602$; ${ }^{1} \mathrm{H}$ NMR (500 MHz, DMSO-d6) $\delta$ (ppm): 12.14 (s, 1H), 7.51-7.52 (d, $\left.J=2 \mathrm{~Hz}, 1 \mathrm{H}\right), 6.94$ (s, 2H), 6.35- 
$6.36(\mathrm{~m}, 1 \mathrm{H}), 6.16-6.17(\mathrm{~d}, J=2.5 \mathrm{~Hz}, 1 \mathrm{H}), 4.76(\mathrm{~s}, 1 \mathrm{H}), 1.96(\mathrm{~s}, 3 \mathrm{H}) ;{ }^{13} \mathrm{C}$ NMR $(100 \mathrm{MHz}, \mathrm{DMSO}-$ $\left.d_{6}\right) \delta$ (ppm): 161.49, 155.72, 154.81, 142.29, 135.83, 120.61, 110.25, 105.65, 95.11, 53.95, 29.81, 9.59; EIMS, $m / z$ [M] ${ }^{+}$calcd: 242.08; found: 242.07; Elemental Analysis for $\mathrm{C}_{12} \mathrm{H}_{10} \mathrm{~N}_{4} \mathrm{O}_{2}$ (\%), Calcd: C, 59.50; H, 4.16; N, 23.13; found: C, 59.45; H, 4.12; N, 23.08.

Ethyl 4-(furan-2-yl)-3-methyl-6-oxo-1,6-dihydropyrano[2, 3-c]pyrazole-5-carboxylate (M14)

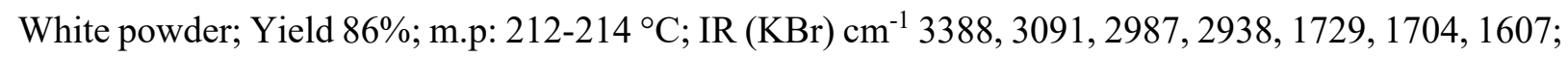
${ }^{1} \mathrm{H}$ NMR (500 MHz, DMSO-d6) $\delta$ (ppm): 12.30 (s, 1H), 7.50 (d, $\left.J=2 \mathrm{~Hz}, 1 \mathrm{H}\right), 6.63-6.64$ (m, 1H), 6.45$6.46(\mathrm{~d}, J=2.5 \mathrm{~Hz}, 1 \mathrm{H}), 4.15-4.19(\mathrm{q}, 2 \mathrm{H}), 2.10(\mathrm{~s}, 3 \mathrm{H}), 1.19-1.23(\mathrm{t}, 3 \mathrm{H}) ;{ }^{13} \mathrm{C}$ NMR $(100 \mathrm{MHz}, \mathrm{DMSO}-$ $\left.d_{6}\right) \delta(\mathrm{ppm}): 164.37,161.64,157.82,157.28,156.55,152.36,143.10,142.01,113.10,108,95.42$, 61.45, 13.63, 10.36; EIMS, $m / z$ [M] $]^{+}$calcd: 288.07; found: 288.05; Elemental Analysis for $\mathrm{C}_{14} \mathrm{H}_{12} \mathrm{~N}_{2} \mathrm{O}_{5}$ (\%), Calcd: C, 58.33; H, 4.20; N, 9.72; found: C, 58.27; H, 4.15; N, 9.67.

Ethyl 6-amino-4-(furan-2-yl)-3-methyl-1,4-dihydropyrano[2, 3-c]pyrazole-5-carboxylate (M15)

White powder; Yield 89\%; m.p: 229-231 ${ }^{\circ} \mathrm{C}$; IR (KBr) cm ${ }^{-1} 3419,3129,3040,2988,2935,1717,1658$, 1622; ${ }^{1} \mathrm{H}$ NMR (500 MHz, DMSO-d6) $\delta(\mathrm{ppm}): 12.22$ (s, 1H), 7.76 (s, 2H), 7.32-7.33 (d, $\left.J=2 \mathrm{~Hz}, 1 \mathrm{H}\right)$, 6.48-6.49 (m, 1H), $6.29(\mathrm{~d}, J=2.5 \mathrm{~Hz}, 1 \mathrm{H}), 5.05(\mathrm{~s}, 1 \mathrm{H}), 4.08-4.14(\mathrm{q}, 2 \mathrm{H}), 1.92(\mathrm{~s}, 3 \mathrm{H}), 1.21-1.25$ (t, $3 \mathrm{H}) ;{ }^{13} \mathrm{C}$ NMR (100 MHz, DMSO- $\left.d_{6}\right) \delta(\mathrm{ppm}): 164.73,159.82,155.45,154.36,142.01,135.80$, 110.18, 105.10, 95.02, 61.09, 59.64, 29.78, 13.36, 10.18; EIMS, $m / z[\mathrm{M}]^{+}$calcd: 289.11; found: 289.10; Elemental Analysis for $\mathrm{C}_{14} \mathrm{H}_{15} \mathrm{~N}_{3} \mathrm{O}_{4}(\%)$, Calcd: C, 58.13; H, 5.23; N, 14.53; found: C, 58.08; H, 5.17; N, 14.49.

6-amino-3-ethoxy-4-(2-hydroxyphenyl)-1,4-dihydropyrano[2, 3-c]pyrazole-5-carbonitrile (M16)

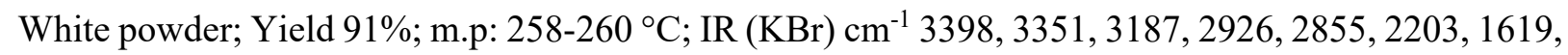
1566; ${ }^{1} \mathrm{H}$ NMR (500 MHz, DMSO-d6) $\delta$ (ppm): 11.23 (s, 1H), 9.62 (s, br, 1H), 7.26-7.28 (m, 1H), 7.1$7.12(\mathrm{~m}, 2 \mathrm{H}), 7.03-7.04(\mathrm{~d}, J=8.5 \mathrm{~Hz}, 1 \mathrm{H}), 6.78(\mathrm{~s}, 2 \mathrm{H}), 4.91(\mathrm{~s}, 1 \mathrm{H}), 4.11-4.17(\mathrm{q}, 2 \mathrm{H}), 1.38-1.41$ (t, $3 \mathrm{H}) ;{ }^{13} \mathrm{C}$ NMR (100 MHz, DMSO- $\left.d_{6}\right) \delta(\mathrm{ppm}): 160.62,159.63,158.80,148.29,131.09,130.29$, 123.60, 123.01, 120.18, 114.55, 104.91, 63.83, 55.11, 35.27, 13.45; EIMS, $m / z[\mathrm{M}]^{+}$calcd: 298.11; found: 298.10; Elemental Analysis for $\mathrm{C}_{15} \mathrm{H}_{14} \mathrm{~N}_{4} \mathrm{O}_{3}$ (\%), Calcd: C, 60.40; H, 4.73; N, 18.78; found: C, $60.35 ; \mathrm{H}, 4.69 ; \mathrm{N}, 18.74$.

6-amino-3-ethoxy-4-(p-tolyl)-1,4-dihydropyrano[2, 3-c]pyrazole-5-carbonitrile (M17)

White powder; Yield 89\%; m.p: 238-240 ${ }^{\circ} \mathrm{C}$; IR (KBr) cm $\mathrm{cm}^{-1} 3447,3417,3351,3058,2986,2921,2862$, 2182, 1624, 1567; ${ }^{1} \mathrm{H}$ NMR (500 MHz, DMSO-d6) $\delta(\mathrm{ppm}): 12.15$ (s, 1H), 7.16-7.18 (d, $J=9.5 \mathrm{~Hz}$, $2 \mathrm{H}), 7.08-7.10(\mathrm{~d}, J=9.5 \mathrm{~Hz}, 2 \mathrm{H}), 6.90(\mathrm{~s}, 2 \mathrm{H}), 5.12(\mathrm{~s}, 1 \mathrm{H}), 4.07-4.13$ (q, 2H), $2.21(\mathrm{~s}, 3 \mathrm{H}), 1.34-1.38$ $(\mathrm{t}, 3 \mathrm{H}) ;{ }^{13} \mathrm{C}$ NMR $\left(100 \mathrm{MHz}, \mathrm{DMSO}-d_{6}\right) \delta$ (ppm): 160.54, 154.36, 153.82, 135.45, 134.91, 128.73, 127.46, 120.37, 97.65, 63.40, 57.09, 35.45, 20.35, 13.12; EIMS, $m / z$ [M] ${ }^{+}$calcd: 296.13; found: 296.11; Elemental Analysis for $\mathrm{C}_{16} \mathrm{H}_{16} \mathrm{~N}_{4} \mathrm{O}_{2}(\%)$, Calcd: C, 64.85; H, 5.44; N, 18.91; found: C, 64.79; H, 5.39; $\mathrm{N}, 18.86$.

6-amino-3-ethoxy-4-(4-methoxyphenyl)-1,4-dihydropyrano[2, 3-c]pyrazole-5-carbonitrile (M18)

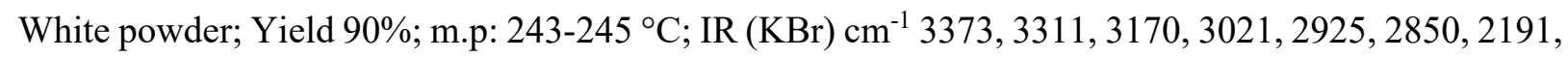
1649, 1599; ${ }^{1} \mathrm{H}$ NMR (500 MHz, DMSO- $\left.d_{6}\right) \delta(\mathrm{ppm}): 12.06$ (s, 1H), 7.05-7.09 (m, 2H), 6.86-6.89 (m, $2 \mathrm{H}), 6.83(\mathrm{~s}, 2 \mathrm{H}), 5.04(\mathrm{~s}, 1 \mathrm{H}), 4.17-4.22(\mathrm{q}, 2 \mathrm{H}), 3.71(\mathrm{~s}, 3 \mathrm{H}), 1.35-1.39(\mathrm{t}, 3 \mathrm{H}) ;{ }^{13} \mathrm{C} \mathrm{NMR}(100 \mathrm{MHz}$, DMSO-d6) $\delta(\mathrm{ppm}): 160.09,159.07,158.37,154.65,136.91,136.36,128.29,121.09,114.18,98.47$, 64.52, 58.18, 54.55, 35.11, 13.62; EIMS, $m / z[\mathrm{M}]^{+}$calcd: 312.12; found: 312.11; Elemental Analysis for $\mathrm{C}_{16} \mathrm{H}_{16} \mathrm{~N}_{4} \mathrm{O}_{3}(\%)$, Calcd: $\mathrm{C}, 61.53 ; \mathrm{H}, 5.16 ; \mathrm{N}, 17.94$; found: $\mathrm{C}, 61.49 ; \mathrm{H}, 5.11 ; \mathrm{N}, 17.88$. 
6-amino-3-ethoxy-4-phenyl-1,4-dihydropyrano[2, 3-c]pyrazole-5-carbonitrile (M19)

White powder; Yield 91\%; m.p: 276-278 ${ }^{\circ} \mathrm{C}$; IR $(\mathrm{KBr}) \mathrm{cm}^{-1}$ 3410, 3378, 3269, 3002, 2923, 2869, 2192 , 1647, 1601; ${ }^{1} \mathrm{H}$ NMR (500 MHz, DMSO-d6) $\delta(\mathrm{ppm}): 12.11(\mathrm{~s}, 1 \mathrm{H}), 7.30-7.33$ (t, 2H), 7.21-7.24 (m, $1 \mathrm{H}), 7.16-7.18(\mathrm{t}, 2 \mathrm{H}), 6.87(\mathrm{~s}, 2 \mathrm{H}), 4.95(\mathrm{~s}, 1 \mathrm{H}), 4.10-4.16(\mathrm{q}, 2 \mathrm{H}), 1.35-1.39(\mathrm{t}, 3 \mathrm{H}) ;{ }^{13} \mathrm{C} \mathrm{NMR}(100$ MHz, DMSO-d6) $\delta(\mathrm{ppm}): 160.70,154.70,154.18,135.27,128.18,127.20,126.47,120.55,97.35$, 64.42, 57.04, 36.12, 13.46; EIMS, $\mathrm{m} / z$ [M] ${ }^{+}$calcd: 282.11; found: 282.11; Elemental Analysis for $\mathrm{C}_{15} \mathrm{H}_{14} \mathrm{~N}_{4} \mathrm{O}_{2}$ (\%), Calcd: C, 63.82; H, 5.00; N, 19.85; found: C, 63.79; H, 4.98; N, 19.82.

6-amino-4-(anthracen-9-yl)-3-ethoxy-1,4-dihydropyrano[2, 3-c]pyrazole-5-carbonitrile (M20)

Brownish white powder; Yield 86\%; m.p: > $300{ }^{\circ} \mathrm{C}$; IR (KBr) cm $\mathrm{cm}^{-1}$ 3456, 3396, 3251, 3050, 2923, 2205, 1671, 1623; ${ }^{1} \mathrm{H}$ NMR (500 MHz, DMSO-d $) \delta(\mathrm{ppm}): 11.91(\mathrm{~s}, 1 \mathrm{H}), 8.19-8.21(\mathrm{~m}, 2 \mathrm{H}), 8$ (s, 1H), 7.66-7.69 (m, 2H), 7.44-7.49 (m, 2H), 7.38-7.43 (m, 2H), 6.79 (s, 2H), 5.20 (s, 1H), 4.12-4.18 (q, $2 \mathrm{H}), 1.34-1.37(\mathrm{t}, 3 \mathrm{H}) ;{ }^{13} \mathrm{C}$ NMR (100 MHz, DMSO-d $) \delta(\mathrm{ppm}): 160.54,154.54,152.35,133.46$, 131.46, 130.91, 130.18, 127.82, 125.64, 122.31, 120.35, 116.36, 98.21, 63.24, 58.90, 29.45, 12.91; EIMS, $m / z$ [M] $]^{+}$calcd: 382.14; found: 382.12; Elemental Analysis for $\mathrm{C}_{23} \mathrm{H}_{18} \mathrm{~N}_{4} \mathrm{O}_{2}$ (\%), Calcd: C, 72.24; H, 4.74; N, 14.65; found: C, 72.18; H, 4.66; N, 14.58 .

6-amino-3-ethoxy-4-(furan-2-yl)-1,4-dihydropyrano[2, 3-c]pyrazole-5-carbonitrile (M21)

White powder; Yield 91\%; m.p: 263-265 ${ }^{\circ} \mathrm{C}$; IR (KBr) cm $\mathrm{cm}^{-1} 3434,3339,3206,2929,2856,2206,1630$, 1577; ${ }^{1} \mathrm{H}$ NMR (500 MHz, DMSO- $\left.d_{6}\right) \delta(\mathrm{ppm}): 12.16(\mathrm{~s}, 1 \mathrm{H}), 7.53-7.54(\mathrm{~d}, J=2 \mathrm{~Hz}, 1 \mathrm{H}), 6.96$ (s, 2H), 6.37-6.38 (m, 1H), $6.18(\mathrm{~d}, J=2.5 \mathrm{~Hz}, 1 \mathrm{H}), 4.92(\mathrm{~s}, 1 \mathrm{H}), 4.08-4.14$ (q, 2H), 1.39-1.43 (t, 3H); ${ }^{13} \mathrm{C} \mathrm{NMR}$ (100 MHz, DMSO-d6) $\delta$ (ppm): 161.46, 156.90, 154.91, 153.64, 142.17, 120.37, 110.13, 105.42, 95.01, 64, 53.28, 29.56, 13.10; EIMS, $\mathrm{m} / z$ [M] ${ }^{+}$calcd: 272.09; found: 272.07; Elemental Analysis for $\mathrm{C}_{13} \mathrm{H}_{12} \mathrm{~N}_{4} \mathrm{O}_{3}$ (\%), Calcd: C, 57.35; H, 4.44; N, 20.58; found: C, 57.30; H, 4.38; N, 20.54.

6-amino-3-methyl-4-(p-tolyl)-1,4-dihydropyrano[2, 3-c]pyrazole-5-carboxylic acid (M22)

White powder; Yield 81\%; m.p: > $300{ }^{\circ} \mathrm{C}$; IR (KBr) cm ${ }^{-1}$ 3464-3186, 3413, 3333, 3278, 3006, 2976, 2918, 1707,1661, 1598; ${ }^{1} \mathrm{H}$ NMR (500 MHz, DMSO- $\left.d_{6}\right) \delta$ (ppm): 12.88 (s, br, 1H), 12.09 (s, 1H), 7.65 (s, 2H), 7.24-7.26 (d, $J=8.5 \mathrm{~Hz}, 2 \mathrm{H}), 7.17-7.19$ (d, $J=8.5 \mathrm{~Hz}, 2 \mathrm{H}), 5.08$ (s, 1H), 2.28 (s, 3H), 1.8 (s, $3 \mathrm{H}) ;{ }^{13} \mathrm{C}$ NMR (100 MHz, DMSO-d6) $\delta(\mathrm{ppm}): 174.55,161.66,154.33,142.01,135.84,135.34$, 128.68, 127.46, 103.33, 60.72, 33.45, 20.67, 10.37; EIMS, $\mathrm{m} / z[\mathrm{M}]^{+}$calcd: 285.11; found: 285.09; Elemental Analysis for $\mathrm{C}_{15} \mathrm{H}_{15} \mathrm{~N}_{3} \mathrm{O}_{3}(\%)$, Calcd: C, 63.15; H, 5.30; N, 14.73; found: C, 63.08; H, 5.21; $\mathrm{N}, 14.66$.

6'-amino-3'-methyl-2-oxo-1'H-spiro[indoline-3,4'-pyrano[2, 3-c]pyrazole]-5'-carbonitrile (M23)

White powder; Yield 82\%; m.p: 279-281 ${ }^{\circ} \mathrm{C}$; IR (KBr) cm $\mathrm{cm}^{-1} 3389,3339,3259,3141,2183,1714,1641$, 1617; ${ }^{1} \mathrm{H}$ NMR (500 MHz, DMSO-d6) $\delta$ (ppm): 12.27 (s, 1H), 10.59 (s, 1H), 7.22-7.25 (m, 3H), 6.97$7.03(\mathrm{~m}, 2 \mathrm{H}), 6.89-6.90(\mathrm{~d}, J=7.5 \mathrm{~Hz}, 1 \mathrm{H}), 1.52(\mathrm{~s}, 3 \mathrm{H}) ;{ }^{13} \mathrm{C}$ NMR (100 MHz, DMSO- $\left.d 6\right) \delta(\mathrm{ppm})$ : 178.04, 162.49, 155.28, 141.52, 134.72, 132.70, 128.91, 124.53, 122.52, 118.76, 109.67, 95.40, 55.15, 47.29, 8.97; EIMS, $m / z$ [M] $]^{+}$calcd: 293.09; found: 293.08; Elemental Analysis for $\mathrm{C}_{15} \mathrm{H}_{11} \mathrm{~N}_{5} \mathrm{O}_{2}(\%)$, Calcd: C, 61.43; H, 3.78; N, 23.88; found: C, 61.38; H, 3.72; N, 23.84.

Ethyl 6'-ethoxy-3'-methyl-2-oxo-1'H-spiro[indoline-3,4'-pyrano[2, 3-c]pyrazole]-5'-carboxylate (M24)

White powder; Yield 78\%; m.p: 240-242 ${ }^{\circ} \mathrm{C}$; IR (KBr) cm $\mathrm{cm}^{-1} 3357,3203,2992,2934,1728,1705,1655$, 1615; ${ }^{1} \mathrm{H}$ NMR (500 MHz, DMSO-d6) $\delta$ (ppm): 12.18 (s, 1H), 10.38 (s, 1H), 7.01-7.04 (m, 3H), 6.98$6.99(\mathrm{~d}, J=6 \mathrm{~Hz}, 1 \mathrm{H}), 4.04-4.07$ (q, $J=7 \mathrm{~Hz}, 2 \mathrm{H}), 3.88-3.91$ (q, $J=7 \mathrm{~Hz}, 2 \mathrm{H}), 1.60$ (s, 3H), 1.13-1.16 
$(\mathrm{t}, J=7 \mathrm{~Hz}, 3 \mathrm{H}), 0.95-0.98(\mathrm{t}, J=7 \mathrm{~Hz}, 3 \mathrm{H}) ;{ }^{13} \mathrm{C}$ NMR (100 MHz, DMSO- $\left.d 6\right) \delta(\mathrm{ppm}): 169.16,167.27$, 163.64, 155, 142.73, 136.84, 134, 128.37, 124, 122.36, 109.46, 97.34, 74.18, 62.83, 61.82, 48.83, 14.17, 13.09, 9.33; EIMS, $m / z$ [M] ${ }^{+}$calcd: 369.13; found: 369.16; Elemental Analysis for $\mathrm{C}_{19} \mathrm{H}_{19} \mathrm{~N}_{3} \mathrm{O}_{5}$ (\%), Calcd: C, 61.78; H, 5.18; N, 11.38; found: C, 61.72; H, 5.12; N, 11.33.

Ethyl 6'-amino-3'-methyl-2-oxo-1'H-spiro[indoline-3,4'-pyrano[2, 3-c]pyrazole]-5'-carboxylate (M25)

White powder; Yield 80\%; m.p: 278-280 ${ }^{\circ} \mathrm{C}$; IR (KBr) $\mathrm{cm}^{-1} 3384,3352,3152,3088,2990,2915,1730$, 1706, 1680, 1620; ${ }^{1} \mathrm{H}$ NMR (500 MHz, DMSO- $\left.d_{6}\right) \delta$ (ppm): 12.17 (s, 1H), 10.37 (s, 1H), 8.02 (s, 2H), 7-7.04 (m, 3H), 6.97-6.98 (d, $J=6 \mathrm{~Hz}, 1 \mathrm{H}), 3.87-3.91$ (q, 2H), 1.58 (s, 3H), 0.99-1.26 (t, 3H); ${ }^{13} \mathrm{C} \mathrm{NMR}$ (100 MHz, DMSO- $\left.d_{6}\right) \delta(\mathrm{ppm}): 180.15,168.80,163.46,154.84,142.91,136,134.17,128.18,123.81$, 122.18, 109.28, 97.16, 74.55, 61.09, 49, 13.64, 9.27; EIMS, $m / z[\mathrm{M}]^{+}$calcd: 340.12 ; found: 340.14; Elemental Analysis for $\mathrm{C}_{17} \mathrm{H}_{16} \mathrm{~N}_{4} \mathrm{O}_{4}(\%)$, Calcd: C, 60.00; H, 4.74; N, 16.46; found: C, 59.94; H, 4.69; $\mathrm{N}, 16.41$.

4-(furan-2-yl)-3-methyl-4,6-dihydropyrazolo[4',3':5,6]pyrano[2,3-d]pyrimidin-5(1H)-one (M26)

Brown powder; Yield 85\%; m.p: 250-252 ${ }^{\circ} \mathrm{C}$; IR (KBr) $\mathrm{cm}^{-1} 3406,3227,3088,2970,1680,1634$, 1597; ${ }^{1} \mathrm{H}$ NMR (500 MHz, DMSO-d6) $\delta$ (ppm): 12.20 (s, 1H), 11.16 (s, 1H), 8.52 (s, 1H), 7.41-7.42 $(\mathrm{d}, J=2 \mathrm{~Hz}, 1 \mathrm{H}), 6.24-6.25(\mathrm{~m}, 1 \mathrm{H}), 6.06(\mathrm{~d}, J=2.5 \mathrm{~Hz}, 1 \mathrm{H}), 5.20(\mathrm{~s}, 1 \mathrm{H}), 2.08(\mathrm{~s}, 3 \mathrm{H}) ;{ }^{13} \mathrm{C} \mathrm{NMR}(100$ MHz, DMSO- $\left.d_{6}\right) \delta$ (ppm): 162.58, 157.79, 156, 154.55, 150.52, 142.90, 136.35, 111.45, 106.90, 99.61, 98.90, 30.31, 10.15; EIMS, $m / z$ [M] $]^{+}$calcd: 270.08; found: 270.06; Elemental Analysis for $\mathrm{C}_{13} \mathrm{H}_{10} \mathrm{~N}_{4} \mathrm{O}_{3}$ (\%), Calcd: C, 57.78; H, 3.73; N, 20.73; found: C, 57.72; H, 3.69; N, 20.68.

\section{3-methyl-4-phenyl-4,6-dihydropyrazolo[4',3':5,6]pyrano[2,3-d]pyrimidin-5(1H)-one (M27)}

White powder; Yield 86\%; m.p: 264-266 ${ }^{\circ} \mathrm{C}$; IR (KBr) cm ${ }^{-1} 3193,3103,3020,2915,1679,1633,1595$; ${ }^{1} \mathrm{H}$ NMR (500 MHz, DMSO-d6) $\delta$ (ppm): 12.12 (s, 1H), 11.13 (s, 1H), 8.34 (s, 1H), 7.34-7.37 (t, 2H), 7.25-7.28 (m, 1H), 7.20-7.22 (t, 2H), $5.22(\mathrm{~s}, 1 \mathrm{H}), 2.24(\mathrm{~s}, 3 \mathrm{H}) ;{ }^{13} \mathrm{C}$ NMR (100 MHz, DMSO-d6) $\delta$ (ppm): 161.83, 159.27, 155.82, 151.46, 144.91, 135.82, 128.91, 127.82, 127.09, 99.45, 98.72, 36.54, 10.71; EIMS, $m / z$ [M] ${ }^{+}$calcd: 280.10; found: 280.11; Elemental Analysis for $\mathrm{C}_{15} \mathrm{H}_{12} \mathrm{~N}_{4} \mathrm{O}_{2}$ (\%), Calcd: C, 64.28; H, 4.32; N, 19.99; found: C, 64.23; H, 4.27; N, 19.94 .

4-(furan-2-yl)-3-methyl-1,4-dihydropyrazolo[4',3':5,6]pyrano[2,3-d]pyrimidin-5-amine (M28)

Brown powder; Yield 84\%; m.p: 268-270 ${ }^{\circ} \mathrm{C}$; IR (KBr) cm ${ }^{-1} 3410,3245,2924,1630,1591 ;{ }^{1} \mathrm{H}$ NMR (500 MHz, DMSO- $\left.d_{6}\right) \delta(\mathrm{ppm}): 12.19(\mathrm{~s}, 1 \mathrm{H}), 8.35$ (s, 1H), 7.61 (d, J=2 Hz, 1H), 7.04 (s, 2H), 6.36$6.37(\mathrm{~m}, 1 \mathrm{H}), 6.17-6.18(\mathrm{~d}, J=2.5 \mathrm{~Hz}, 1 \mathrm{H}), 5.21(\mathrm{~s}, 1 \mathrm{H}), 2.16(\mathrm{~s}, 3 \mathrm{H}) ;{ }^{13} \mathrm{C}$ NMR $(100 \mathrm{MHz}, \mathrm{DMSO}-$ $\left.d_{6}\right) \delta$ (ppm): 163.64, 159.11, 157.21, 155.82, 152.91, 143.09, 136.54, 112.38, 107.81, 100.54, 99.62, 31.24, 10.34; EIMS, $m / z$ [M] $]^{+}$calcd: 269.09; found: 269.11; Elemental Analysis for $\mathrm{C}_{13} \mathrm{H}_{11} \mathrm{~N}_{5} \mathrm{O}_{2}(\%)$, Calcd: C, 57.99; H, 4.12; N, 26.01; found: C, 57.93; H, 4.07; N, 25.97.

3-methyl-4-phenyl-1,4-dihydropyrazolo[4',3':5,6]pyrano[2,3-d]pyrimidin-5-amine (M29)

White powder; Yield 86\%; m.p: 284-286 ${ }^{\circ} \mathrm{C}$; IR (KBr) cm ${ }^{-1} 3378,3208,2923,1627,1566$; ${ }^{1} \mathrm{H}$ NMR (500 MHz, DMSO-d6) $\delta(\mathrm{ppm}): 12.13(\mathrm{~s}, 1 \mathrm{H}), 8.39(\mathrm{~s}, 1 \mathrm{H}), 7.32-7.35(\mathrm{t}, 2 \mathrm{H}), 7.21-7.26(\mathrm{~m}, 1 \mathrm{H}), 7.18-$ 7.19 (t, 2H), 6.85 (s, 2H), 5.19 (s, 1H), 2.18 (s, 3H); ${ }^{13} \mathrm{C}$ NMR (100 MHz, DMSO- $\left.d 6\right) \delta(\mathrm{ppm}): 163.10$, 158.54, 156.54, 155.28, 145.27, 136.19, 129.09, 128.17, 127.46, 100.18, 99.45, 37.45, 10.91; EIMS, $m / z$ [M] ${ }^{+}$calcd: 279.11; found: 279.08; Elemental Analysis for $\mathrm{C}_{15} \mathrm{H}_{13} \mathrm{~N}_{5} \mathrm{O}(\%)$, Calcd: C, 64.51; $\mathrm{H}$, 4.69; N, 25.07; found: C, 64.46; H, 4.63; N, 25.02. 

(M30)

Brown powder; Yield 87\%; m.p: 280-282 ${ }^{\circ} \mathrm{C}$; IR (KBr) cm $\mathrm{cm}^{-1} 3451,3123,3025,2933,1674,1643$, 1603; ${ }^{1} \mathrm{H}$ NMR (500 MHz, DMSO-d6) $\delta(\mathrm{ppm}): 12.21(\mathrm{~s}, 1 \mathrm{H}), 11.51(\mathrm{~s}, 1 \mathrm{H}), 7.52(\mathrm{~d}, J=2 \mathrm{~Hz}, 1 \mathrm{H})$, 6.35-6.36 (m, 1H), 6.16-6.17 (d, $J=2.5 \mathrm{~Hz}, 1 \mathrm{H}), 5.19(\mathrm{~s}, 1 \mathrm{H}), 2.24(\mathrm{~s}, 3 \mathrm{H}), 1.91(\mathrm{~s}, 3 \mathrm{H}) ;{ }^{13} \mathrm{C}$ NMR $(100$ MHz, DMSO- $\left.d_{6}\right) \delta(\mathrm{ppm}): 162.90,157.36,156.37,155.63,153.10,143.10,138.91,112.17,107.45$, 99.80, 99.07, 30.52, 20.18, 10.34; EIMS, $m / z$ [M] $]^{+}$calcd: 284.09; found: 284.08; Elemental Analysis for $\mathrm{C}_{14} \mathrm{H}_{12} \mathrm{~N}_{4} \mathrm{O}_{3}(\%)$, Calcd: C, 59.15; H, 4.26; N, 19.71; found: C, 59.10; H, 4.21; N, 19.67 .

3,7-dimethyl-4-phenyl-4,6-dihydropyrazolo[4',3':5,6]pyrano[2,3-d]pyrimidin-5(1H)-one (M31)

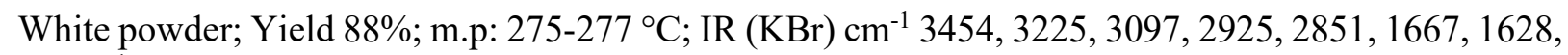
1601; ${ }^{1} \mathrm{H}$ NMR $\left(500 \mathrm{MHz}, \mathrm{DMSO}-d_{6}\right) \delta(\mathrm{ppm}): 12.23(\mathrm{~s}, 1 \mathrm{H}), 11.50(\mathrm{~s}, 1 \mathrm{H}), 7.22-7.25(\mathrm{t}, 2 \mathrm{H}), 7.13-$ $7.16(\mathrm{~m}, 1 \mathrm{H}), 7.08-7.10(\mathrm{t}, 2 \mathrm{H}), 5.18(\mathrm{~s}, 1 \mathrm{H}), 2.23(\mathrm{~s}, 3 \mathrm{H}), 1.92(\mathrm{~s}, 3 \mathrm{H}) ;{ }^{13} \mathrm{C}$ NMR $(100 \mathrm{MHz}$, DMSO$\left.d_{6}\right) \delta$ (ppm): 162.37, 158, 155.82, 155.09, 143.09, 136.01, 129.09, 128, 127.27, 99.64, 98.91, 36.18, 20.90, 10.90; EIMS, $m / z$ [M] ${ }^{+}$calcd: 294.11; found: 294.08; Elemental Analysis for $\mathrm{C}_{16} \mathrm{H}_{14} \mathrm{~N}_{4} \mathrm{O}_{2}(\%)$, Calcd: C, 65.30; H, 4.79; N, 19.04; found: C, 65.25; H, 4.73; N, 18.99 .

\subsection{Biological evaluation}

The diverse biological efficiencies of pyrano[2, 3-c]pyrazole derivatives inspired us to evaluate the antimicrobial efficacy of the new synthetic compounds.

\subsubsection{Antimicrobial screening}

Many antimicrobial agents have now been applied for treatment; In order to get over the highly resistant species of the microorganisms, the medical field still needs widespread efforts to develop new antimicrobial agents. All the synthetic compounds were tested in vitro by broth dilution assay, as minimum inhibitory concentration (MIC), for their anti-bacterial and antifungal activity. For every standard strain acquired from Gene Bank and the Microbial Type Culture Collection (MTCC), Institute of Microbial Technology, Chandigarh, India, triplicates were done.

Culture media: For this study, nine microorganisms were chosen: Gram-negative bacteria (Salmonella typhi (S. typhi) MTCC 98, Pseudomonas aeruginosa (P. aeruginosa) MTCC 1688, and Vibrio cholerae (V. cholerae) MTCC 3906), Gram-positive bacteria (Bacillus subtilis (B. subtilis) MTCC 441, Clostridium tetani (C. tetani) MTCC 449, and Streptococcus pneumoniae (S. pneumoniae) MTCC 1936), and three strains of fungi (Candida krusei (C. krusei) MTCC 3020, Aspergillus fumigatus (A. fumigatus) MTCC 3008, and Aspergillus niger (A. niger) MTCC 282) taking ciprofloxacin, griseofulvin, and nystatin as standard antibiotics. Prior to the vehicle testing, all microorganisms were previously subcultured under gaseous conditions and in suitable media (HIMEDIA M210-500) for $48 \mathrm{~h}$ at $35^{\circ} \mathrm{C}$ to check their purity.

Inoculum preparation: The growth method was carried out as follows. From an agar culture plate, at least three to five well-isolated colonies have been chosen with the same morphology. A loop was used to scoop the top of each colony, followed by transporting the growth into a tube holding 5 $\mathrm{mL}$ of Brain Heart Infusion (BHI) broth. At $35^{\circ} \mathrm{C}$, the incubation of the broth culture lasted for 2-6 h, till accomplishing the 0.5 turbidity of McFarland reference. To achieve definitive turbidity optically analogous to the 0.5 turbidity of McFarland reference, the effectively developing turbidity of the broth culture was modified utilizing broth, and this was visually performed by comparing the standard and the inoculum tube versus a white card involving contradicting black lines.

\subsubsection{Broth dilution assay}


A total of 10 tubes were prepared, and nine vehicle dilutions were performed with BHI for MIC. In the first tube, just $200 \mu \mathrm{L}$ of the vehicle was applied. $200 \mu \mathrm{L}$ of the broth of BHI was individually applied to the subsequent nine tubes for further dilutions. $200 \mu \mathrm{L}$ of the vehicle inclusive $200 \mu \mathrm{L}$ of $\mathrm{BHI}$ broth was appended to the second tube and regarded as 10 dilution. 10 dilution was made from the 10 mitigated tube by transfer of $200 \mu \mathrm{L}$ to the second tube. For each vehicle, the sequent dilution was replicated over until 10 dilution. $5 \mu \mathrm{L}$ was taken from the required microorganisms preserved stock cultures and applied to $2 \mathrm{~mL}$ of the broth of BHI. $200 \mu \mathrm{L}$ of the preceding culture suspension was inserted in each sequentially diluted tube. Only the culture suspension and the media were included in the last tube as a negative control. For incubation, the tubes were reserved in a bacteriological incubator for $24 \mathrm{~h}$ at $37^{\circ} \mathrm{C}$, and the turbidity was detected and observed.

\subsubsection{Computational Studies}

The structures of the all-tested compounds were modelled utilizing the Chemsketch software (http://www.acdlabs.com/resources/ freeware/). Using VEGA ZZ software, the structures were enhanced and energy minimalized. ${ }^{47}$ The optimized compounds were applied to execute molecular docking against both CDK2 and penicillin-binding protein. From Protein Data Bank (PDB) (www.rcsb.org): (PDB: 3UDI, https://www.rcsb.org/structure/3UDI), and (PDB: 1DI8, https://www.rcsb.org/structure/1di8), the molecular target three-dimensional structure was gained. The eradicating of heteroatoms (water and ions), the charge assignment, and adding polar hydrogen were comprised in the receptor preparation steps. The suitable sized-grid boxes round the restrictive cocrystal ligands were used to define the active sites. Autodock vina and Chimera were utilized for visualization in performing the docking study. ${ }^{48,49}$

\section{References}

1 Beerappa M., Shivashankar K. (2018) Four component synthesis of highly functionalized pyrano [2, 3-c] pyrazoles from benzyl halides. Synthetic commun., 48 (2) 146-154.

2 Maddila S., Gorle S., Shabalala S., Oyetade O., Maddila S. N., Lavanya P., Jonnalagadda S. B. (2019) Ultrasound mediated green synthesis of pyrano [2, 3-c] pyrazoles by using $\mathrm{Mn}$ doped $\mathrm{ZrO}_{2}$. Arab. J. Chem., 12 (5) 671-679.

3 Vasuki G., Kumaravel K. (2008) Rapid four-component reactions in water: synthesis of pyranopyrazoles. Tetrahedron Lett., 49 (39) 5636-5638.

4 Zolfigol M. A., Tavasoli M., Moosavi-Zare A. R., Moosavi P., Kruger H. G., Shiri M., Khakyzadeh V. (2013) Synthesis of pyranopyrazoles using isonicotinic acid as a dual and biological organocatalyst. RSC Adv., 3 (48) 25681-25685.

5 Liang J., Seydimemet M., Ghalip Z., Ablajan K. (2019) $\mathrm{InCl}_{3}$-catalyzed one-pot synthesis of multi-substituted pyrano [2, 3-c] pyrazole-4-carboxylic acid esters under ultrasound irradiation. Mol. Divers., 23 (2) 275-282.

6 Azizi N., Edrisi M. (2017) Multicomponent reaction in deep eutectic solvent for synthesis of substituted 1aminoalkyl-2-naphthols. Res. Chem. Intermed., 43 (1) 379-385.

7 Ugi I. (2001) Recent progress in the chemistry of multicomponent reactions. Pure Appl. Chem., 73 (1) 187191.

8 Mamaghani M., Hossein Nia. R. (2019) A review on the recent multicomponent synthesis of pyranopyrazoles. Polycycl. Aromat. Compd., 1-69.

9 Amirnejat S., Nosrati A., Peymanfar R., Javanshir S. (2020) Synthesis and antibacterial study of 2-amino-4 Hpyrans and pyrans annulated heterocycles catalyzed by sulfated polysaccharide-coated $\mathrm{BaFe}_{12} \mathrm{O}_{19}$ nanoparticles. Res. Chem. Intermed., 46 3683-3701.

10 Bensaber S. M., Allafe H. A., Ermeli N. B., Mohamed S. B., Zetrini A. A., Alsabri S. G., Erhuma M., Hermann A., Jaeda M. I., Gbaj A. M. (2014) Chemical synthesis, molecular modelling, and evaluation of anticancer activity of some pyrazol-3-one Schiff base derivatives. Med. Chem. Res., 23 (12) 5120-5134.

11 Hojati S. F., Amiri A., Mohamadi S., MoeiniEghbali N. (2018) Novel organometallic nanomagnetic catalyst for multicomponent synthesis of spiroindoline derivatives. Res. Chem. Intermed., 44 (4) 2275-2287.

12 Abd El-Aal R. M., Younis M. (2004) Synthesis and antimicrobial activity of certain novel monomethine cyanine dyes. Dyes Pigm., 60 (3) 205-214.

13 Wei J., Gui W., Cui Y., Zhang Z., Yousif Q. A. (2020) SCMNPs@, Uridine/Zn: An efficient and reusable heterogeneous nanocatalyst for the rapid one-pot synthesis of tricyclic fused pyrazolopyranopyrimidine and 
3-methyl carboxylate substituted pyrano [2,3-c] pyrazole derivatives under solvent-free conditions. Pol. J. Chem. Technol., 22 (2) 20-33.

14 Labana B. M., Brahmbhatt G. C., Sutariya T. R., Parmar N. J., Padrón J. M., Kant R., Gupta V. K. (2017) Efficient synthesis and biological evaluation of new benzopyran-annulated pyrano $[2,3-c]$ pyrazole derivatives. Mol. Divers., 21(2) 339-354.

15 Sun X., Zhang L., Gao M., Que X., Zhou C., Zhu D., Cai Y. (2019). Nanoformulation of a Novel Pyrano [2, 3-c] Pyrazole Heterocyclic Compound AMDPC Exhibits Anti-Cancer Activity via Blocking the Cell Cycle through a P53-Independent Pathway. Molecules, 24 (3) 624.

16 Maddila S. N., Maddila S., van Zyl W. E., Jonnalagadda S. B. (2017) $\mathrm{CeO}_{2} / \mathrm{ZrO}_{2}$ as green catalyst for onepot synthesis of new pyrano [2, 3-c]-pyrazoles. Res. Chem. Intermed., 43 (8) 4313-4325.

17 Das D., Banerjee R., Mitra A. (2014). Bioactive and pharmacologically important pyrano [2, 3-c] pyrazoles. J. Chem. Pharm. Res., 6 (11) 108-116.

18 Abdelrazek F. M., Michael F. A., Mohamed A. E. (2006) Synthesis and Molluscicidal Activity of Some 1, 3 , 4-Triaryl-5-chloropyrazole, Pyrano [2, 3-c] pyrazole, Pyrazolylphthalazine and Pyrano [2, 3- $d$ ] thiazole Derivatives. Arch Pharm: Int. J. Pharm. Med. Chem., 339 (6) 305-312.

19 Dabholkar V. V., Kurade S. K., Badhe K. S. (2016) One Pot Synthesis of 4H-Pyrano[2, 3-c] Pyrazole using Ni-Ferrite Nanoparticles. Heterocycl. Lett., 6 (4) 767-774.

20 Mariappan G., Saha B. P., Sutharson L., Ankits G., Pandey L., Kumar D. (2010) The diverse pharmacological importance of pyrazolone derivatives: A Review. J. Pharm. Res., 3 (12) 2856-2859.

21 Moosavi-Zare A. R., Afshar-Hezarkhani H., Rezaei M. M. (2020) Tandem Four Component Condensation Reaction of Aryl Aldehydes with Ethyl Acetoacetate, Malononitrile, and Hydrazine Hydrate using Boric Acid in Water as an Efficient and Green Catalytic System. Polycycl. Aromat. Compd., 40 (1) 150-158.

22 Maarop M. S., Rashid F. N. A. A., Mohammat M. F., Shaameri Z., Johari S. A., Isa M. M., Low A. L. M. (2020) New Access to Pyrano $[2,3-c]$ pyrazole-3-carboxylates via Domino Four-Component Reaction and Their Antimicrobial Activity. Indones. J. Chem., 20 (1) 60-71.

23 Ali E., Naimi-Jamal M. R., Ghahramanzadeh R. (2019) One-Pot Multicomponent Synthesis of Pyrano [2,3 c] pyrazole Derivatives Using $\mathrm{CMCSO}_{3} \mathrm{H}$ as a Green Catalyst. Chemistry Select, 4 (31) 9033-9039.

24 Mecadon H., Rohman M. R., Kharbangar I., Laloo B. M., Kharkongor I., Rajbangshi M., Myrboh B. (2011) L-Proline as an efficicent catalyst for the multi-component synthesis of 6-amino-4-alkyl/aryl-3-methyl-2, 4dihydropyrano [2, 3-c] pyrazole-5-carbonitriles in water. Tetrahedron Lett., 52 (25) 3228-3231.

25 Kiyani H., Samimi H., Ghorbani F., Esmaieli S. (2013) One-pot, four-component synthesis of pyrano [2, 3c] pyrazoles catalyzed by sodium benzoate in aqueous medium. Curr. Chem. Lett., 2 (4) 197-206.

26 Hafez E. A., Elnagdi M. H., Elagamey A. G., El-Taweel F. M. (1987) Nitriles in heterocyclic synthesis: novel synthesis of benzo $[c]$-coumarin and of benzo $[c]$ pyrano $[3,2-c]$ quinoline derivatives. Heterocycles, 26 (4) 903-907.

27 Ahmad M. R., Mohammed A. H. A., Ali Y., Al-Messri Z. A. (2014) Synthesis, Characterization and Evaluation of Some Pyranopyrazoles and Pyranopyrimidines Derivatives as Antioxidants for Lubricating Oils. Iraqi J. Sci., 55 (1) 1-11.

28 Yadav D. K., Quraishi M. A. (2012) Electrochemical investigation of substituted pyranopyrazoles adsorption on mild steel in acid solution. Ind. Eng. Chem. Res., 51 (24) 8194-8210.

29 Fadda A. A., El-Mekabaty A., Elattar K. M. (2013) Chemistry of enaminonitriles of pyrano [2, 3-c] pyrazole and related compounds. Synthetic Commun., 43 (20) 2685-2719.

30 Paul S., Pradhan K., Ghosh S., De S. K., Das A. R. (2014) Uncapped $\mathrm{SnO}_{2}$ quantum dot catalyzed cascade assembling of four components: a rapid and green approach to the pyrano $[2,3-c]$ pyrazole and spiro-2oxindole derivatives. Tetrahedron, 70 (36) 6088-6099.

31 Myrboh B., Mecadon H., Rohman M. R., Rajbangshi M., Kharkongor I., Laloo B. M., Kharbangar I., Kshiar B. (2013) Synthetic developments in functionalized pyrano [2, 3-c] pyrazoles. A review. Org. Prep. Proced. Int., 45(4) 253-303.

32 Junek H., Aigner H., Tacconi G., Gatti G., Desimoni G., Messori V. J., Shestopalov A. M., Emeliyanova Y. M., Shestopalov A. A., Rodinovskaya L. A., Niazimbetova Z. I. (1973) Cross-condensation of derivatives of cyanoacetic acid and carbonyl compounds, part 1: Single-stage synthesis of 1'-substituted 6-amino-spiro-4(piperidine-4')-2H,4H-pyrano [2, 3-c] pyrazole-5-carbonitriles. Chem. Ber., 106 914-921.

33 Al-Matar H. M., Khalil K. D., Adam A. Y., Elnagdi M. H. (2010) Green one pot solvent-free synthesis of pyrano [2, 3-c]-pyrazoles and pyrazolo [1, 5-a] pyrimidines. Molecules, 15 (9) 6619-6629.

34 Reddy M. M., Jayashankara V. P., Pasha M. A. (2010) Glycine-catalyzed efficient synthesis of pyranopyrazoles via one-pot multicomponent reaction. Synthetic Commun., 40 (19) 2930-2934. 
35 Gogoi S., Zhao C. G. (2009) Organocatalyzed enantioselective synthesis of 6-amino-5-cyanodihydropyrano [2, 3-c] pyrazoles. Tetrahedron lett., 50 (19) 2252-2255.

36 Shestopalov A. M., Emeliyanova Y. M., Shestopalov A. A., Rodinovskaya L. A., Niazimbetova Z. I., Evans D. H. (2002) One-Step Synthesis of Substituted 6-Amino-5-cyanospiro-4-(piperidine-4')-2 H, $4 \mathrm{H}$ dihydropyrazolo [3, 4-b] pyrans. Organic lett., 4 (3) 423-425.

37 Khazdooz L., Zarei, A. (2016) Brönsted acidic ionic liquid as a recyclable catalyst for the one pot fourcomponent synthesis of substituted pyrano [2, 3-c] pyrazoles. Iran. J. Catal., 6 (1) 69-74.

38 Yanfang S., Hualai W., Hui B. (2020) A coumarin-based turn-on chemosensor for selective detection of $\mathrm{Zn}$ (II) and application in live cell imaging. Spectrochim. Acta Part A: Mol. Biomol. Spectrosc., 228, 117746.

39 Ahadi S., Yasaei Z., Bazgir A. (2010) A clean and one-pot synthesis of spiroindoline-pyranopyrazoles. $J$. Heterocyclic Chem., 47 (5) 1090-1094.

40 Guo R. Y., An Z. M., Mo L. P., Yang S. T., Liu H. X., Wang S. X., Zhang Z. H. (2013) Meglumine promoted one-pot, four-component synthesis of pyranopyrazole derivatives. Tetrahedron., 69 (47) 9931-9938.

41 Fadda A. A., Etman H. A., El-Seidy M. Y., Elattar K. M. (2012) Utility of enaminonitriles in heterocyclic synthesis: synthesis of some new pyrazole, pyridine, and pyrimidine derivatives. Am. J. Org. Chem., 49 (4) 774-781.

42 Roma G., Di Braccio M., Carrieri A., Grossi G., Leoncini G., Signorello M. G., Carotti A. (2003) Coumarin, chromone, and $4(3 H)$-pyrimidinone novel bicyclic and tricyclic derivatives as antiplatelet agents: synthesis, biological evaluation, and comparative molecular field analysis. Bioorg. Med. Chem., 11 (1) 123-138.

43 Ghate M., Kusanur R. A., Kulkarni M. V. (2005) Synthesis and in vivo analgesic and anti-inflammatory activity of some bi heterocyclic coumarin derivatives. Eur. J. Med. Chem., 40 (9) 882-887.

44 Zgoda J. R., Porter J. R. (2001) A convenient microdilution method for screening natural products against bacteria and fungi. Pharm. Biol., 39 (3) 221-225.

45 Chougala B. M., Samundeeswari S., Holiyachi M., Shastri L. A., Dodamani S., Jalalpure S., Dixit S. R., Joshi S. D., Sunagar V. A. (2017) Synthesis, characterization and molecular docking studies of substituted 4coumarinylpyrano $[2,3-c]$ pyrazole derivatives as potent antibacterial and anti-inflammatory agents. Eur. $J$. Med. Chem., 125, 101-116.

46 Krčméry V., Matejička F., PichňovÁ E., Jurga Ĺ., Sulcova M., Kunová A., West D. (1999) Documented fungal infections after prophylaxis or therapy with wide spectrum antibiotics: relationship between certain fungal pathogens and particular antimicrobials? J. chemother., 11(5) 385-390.

47 Pedretti A., Villa L., Vistoli G. (2004) VEGA-an open platform to develop chemo-bio-informatics applications, using plug-in architecture and script programming. J. Comput. Aided Mol. Des., 18 (3) 167-173.

48 Vina A. (2010) Improving the speed and accuracy of docking with a new scoring function, efficient optimization, and multithreading Trott, Oleg; Olson, Arthur J. J. Comput. Chem., 31 (2) 455-461.

49 Pettersen, E. F., Goddard, T. D., Huang, C. C., Couch, G. S., Greenblatt, D. M., Meng, E. C., Ferrin, T. E. (2004) UCSF Chimera - a visualization system for exploratory research and analysis. J. comput. Chem., 25 (13) $1605-1612$.

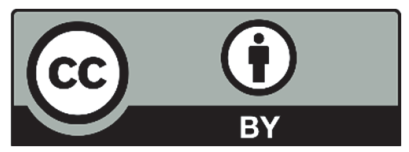

(C) 2021 by the authors; licensee Growing Science, Canada. This is an open access article distributed under the terms and conditions of the Creative Commons Attribution (CC-BY) license (http://creativecommons.org/licenses/by/4.0/). 